\title{
Corporate tax avoidance and industry concentration ${ }^{1}$
}

\author{
Julien Martin*, Mathieu Parenti ${ }^{\dagger}$ and Farid Toubal ${ }^{\ddagger}$
}

\section{Highlights}

- Tax avoidance by large corporations has contributed to the $25 \%$ increase in concentration among U.S. firms since the mid-1990s.

- Corporate tax avoidance gives large firms a competitive edge, which translates into larger market shares and an increase in the granularity of the economy.

- Develop IV and difference-in-differences strategies that show the causal impact of tax avoidance on firmlevel sales.

- Had firms not resorted to tax avoidance in 2017 , our results imply that the average industry concentration would have been $8.3 \%$ lower, which is around its early 2000 level.

\footnotetext{
1. 1We wish to thank Andrew Clark, Peter Egger, Gabrielle Fack, James Hines, Elise Huillery, Florian Mayneris, Sophie Osotimehin, Leslie Robinson, Bridget Stomberg and seminar participants at CEPII, ENS Paris-Saclay, Université Paris-Dauphine, and the UQAM "Corporate Taxation in a Globalized World" virtual conference meetings for useful comments and discussions. We are particularly thankful to Baptiste Souillard for sharing information with us. We wish to thank the ENS Paris-Saclay Booster's program for fundings. Martin is supported in part by funding from the Social Sciences and Humanities Research Council, and by the UQAM research chair on the local impact of multinationals.

† Université Libre de Bruxelles and CEPR: mparenti@ulb.ac.be.

$\ddagger$ ENS Paris-Saclay, CEPII, CESifo and CEPR: ftoubal@ens-cachan.fr.
} 


\section{Abstract}

This paper argues that tax avoidance by large corporations has contributed to the $25 \%$ increase in concentration among U.S. firms since the mid-1990s. Corporate tax avoidance gives large firms a competitive edge, which translates into larger market shares and an increase in the granularity of the economy. We develop IV and differencein-differences strategies that show the causal impact of tax avoidance on firm-level sales. Had firms not resorted to tax avoidance in 2017, our results imply that the average industry concentration would have been $8.3 \%$ lower, which is around its early 2000 level.

\section{Keywords}

Tax Avoidance, Industry Concentration, IRS Audit Probability.<smiles>[AlH2][AlH2]</smiles>

D22, H26, L11, D4, F23.

\section{Working Paper}

CEPII (Centre d'Etudes Prospectives et d'Informations Internationales) is a French institute dedicated to producing independent, policyoriented economic research helpful to understand the international economic environment and challenges in the areas of trade policy, competitiveness, macroeconomics, international finance and growth.

CEPII Working Paper
Contributing to research in international
economics
@ CEPII, PARIS, 2020
All rights reserved. Opinions expressed
in this publication are those of the
author(s) alone.

Editorial Director: Sébastien Jean

Production: Laure Boivin

Published on 23.07.20

No ISSN: $1293-2574$
CEPII

20, avenue de Ségur TSA 10726 75334 Paris Cedex 07 +33153685500 www.cepii.fr Press contact: presse@cepii.fr 


\title{
Corporate tax avoidance and industry concentration ${ }^{1}$
}

\author{
Julien Martin* Mathieu Parenti ${ }^{\dagger}$ and Farid Toubal ${ }^{\ddagger}$
}

\section{Introduction}

A wealth of empirical evidence suggests concentration among U.S. firms has increased since the early $90 \mathrm{~s}^{2}$ A similar upward trend occurs for aggressive corporate tax avoidance and profit shifting of U.S. firms. ${ }^{3}$ Whereas the previous literature has highlighted the role of technology (Autor et al., 2020), increasing barriers to entry, lax or ineffective antitrust enforcement (Gutiérrez and Philippon, 2018; Philippon, 2019) to explain the increase in concentration, we investigate the role of corporate tax avoidance.

This paper shows that the relative increase in tax avoidance by large corporations has contributed

\footnotetext{
${ }^{1}$ We wish to thank Andrew Clark, Peter Egger, Gabrielle Fack, James Hines, Elise Huillery, Florian Mayneris, Sophie Osotimehin, Leslie Robinson, Bridget Stomberg and seminar participants at CEPII, ENS Paris-Saclay, Université Paris-Dauphine, and the UQAM "Corporate Taxation in a Globalized World" virtual conference meetings for useful comments and discussions. We are particularly thankful to Baptiste Souillard for sharing information with us. We wish to thank the ENS Paris-Saclay Booster's program for fundings. Martin is supported in part by funding from the Social Sciences and Humanities Research Council, and by the UQAM research chair on the local impact of multinationals.

*Université du Québec à Montréal and CEPR: martin.julien@uqam.ca.

†Université Libre de Bruxelles and CEPR: mparenti@ulb.ac.be.

¥ENS Paris-Saclay, CEPII, CESifo and CEPR: ftoubal@ens-cachan.fr.

${ }^{2} \mathrm{~A}$ handful of businesses account for most of the sales in each sector, a phenomenon that drives economy-wide concentration and has been described in many studies, including important papers such as Autor et al. (2017), Grullon, Larkin and Michaely (2019), Furman and Orszag (2015), Philippon (2019), De Loecker, Eeckhout and Unger (2020), or Shambaugh et al. (2018).

${ }^{3}$ We define corporate tax avoidance as a broad spectrum of activities ranging from the exploitation of uncertainties or variability in the interpretation of the tax law to arrangements or schemes designed specifically to reduce taxable income that may be illegal, including tax evasion (Hanlon and Heitzman, 2010), Chen et al. (2010). For recent discussions on the spread and magnitude of tax avoidance, see Blouin and Robinson (2019) and Clausing (2016, 2020).
} 
to an increase in the granularity of the U.S. economy. We provide causal evidence on the impact of tax avoidance on firm-level sales, and we demonstrate this competitive edge has mostly benefited the largest companies and thus fostered industry concentration. ${ }^{4}$ This new finding is critical for two reasons. First, it challenges the debate on the sources of concentration by highlighting an additional channel - tax avoidance. Second, it illustrates how the implications of corporate tax avoidance go beyond the erosion of government tax revenues. ${ }^{5}$ By affecting the granularity of the economy, tax avoidance may have end effects on various outcomes such as the political influence of the largest firms (Zingales, 2017) or the exposure of the economy to granular shocks (Gabaix, 2011).

Our empirical analysis uses firm-level financial information from the Compustat database for the period 1991-2017. The dataset includes firms that are (or have been) publicly traded. It is well suited to examining our economic question, because it provides information consolidated at the firm level on worldwide sales, cash tax paid, and pre-tax income profits, as well as a wealth of financial information including detailed sectors of activity and state of incorporation. About $35 \%$ of reported pre-tax income in the sample is negative. We follow the methodology of Henry and Sansing (2018) to compute a measure of tax avoidance that takes into account negative pre-tax income.

The paper starts by establishing a set of facts on concentration and tax avoidance. We confirm in our sample the upward trend of concentration across most U.S. industries. Whereas tax avoidance has increased across all sectors, but with different intensities, we document that it is larger among big firms than among smaller firms. Using external information from IRS Annual Databooks, we then show the probability of IRS audit has declined steadily for the largest U.S. firms since 1991,

\footnotetext{
${ }^{4} \mathrm{~A}$ few papers have documented a positive correlation between tax avoidance and firms' size (Gumpert, Hines and Schnitzer, 2016; Davies et al., 2018), or their product market power (Kubick et al., 2014). These papers interpret this correlation as evidence that tax avoidance is a costly activity that large corporations are more likely to afford. Our paper instead provides evidence for the causal impact of tax avoidance on sales. Note, however, that competition has also been found to increase tax avoidance (Cai and Liu, 2009).

${ }^{5}$ See Clausing (2016) or Zucman (2014) about the government losses induced by the tax avoidance of large multinationals.
} 
while remaining relatively constant for the smallest firms. Importantly, we show a positive correlation between the level of concentration in a sector and the dispersion in the level of tax avoidance across firms in this sector. This finding suggests higher levels of concentration in industries where some firms have greater potential to lower their corporate tax burden.

To frame our empirical analysis, we discuss the theoretical determinants of the heterogeneity of firm-level sales within sectors. In our stylized model, firms are heterogeneous with respect to their productivity and also to their ability to reduce pre-tax profits. We show tax avoidance gives a competitive edge to profit-shifting firms by reducing their effective marginal costs. When firms have the same level of tax avoidance, sales dispersion in the economy is entirely driven by differences in productivity. If tax avoidance is facilitated uniformly, firms' profitability increases, but their relative sales are not affected. In this framework, the level of tax avoidance does not drive sales dispersion. Instead, a dispersion in the degree of tax avoidance across firms contributes to sales dispersion as suggested by the facts. If large firms adopt more aggressive tax-avoidance strategies, concentration rises up.

The econometric analysis uses the rich structure of the Compustat dataset to analyze the impact of tax avoidance on firms' sales. Because large firms are also more likely to follow more aggressive tax-planning strategies than smaller firms, we follow an instrumental strategy approach to assess the causal impact of tax avoidance on sales. Our instrument is computed from the IRS audit probability. According to Hoopes, Mescall and Pittman (2012), lower audit probabilities are associated with more tax avoidance. We thus exploit individual fluctuations in audit probability to identify the effect of tax avoidance on firm-level sales. Our first-stage results show a negative correlation between the audit probability and tax avoidance. In line with Schwab, Stomberg and Xia (2019), this finding suggests the HS-gap measure captures well cross-firm differences in tax avoidance. In line with the main theoretical prediction, our econometric estimates show a positive impact of aggressive tax- 
avoidance strategies on firms' sales. The result is robust to the inclusion of factors that have proven to be important in previous literature, such as the level of productivity, the share of intangible assets, the likelihood of acquisition, the firm's multinational status, or the $R \& D$ intensity. We further show this relationship is stronger in service sectors, for firms with a larger share of intangibles and with a multinational status.

We confirm the causal impact of tax avoidance on sales in a second exercise in which we exploit a change in US legislation that exempts firms from reporting the precise geography of their geographic earning after 1998. We study the impact of the SFAS 131 reform on the sales and tax avoidance behavior of firms active abroad relative to other firms, before and after the reform. Consistent with Hope, Ma and Thomas (2013), we find the reform has enhanced the tax avoidance of firms with foreign operations. We then use the implementation of the legislation to instrument the change in tax avoidance and show its end-effect on sales.

Industry concentration increased by $25 \%$ in the U.S. between 1995 and 2017. Based on our empirical estimates, we propose two quantification exercises of the impact of tax avoidance on concentration. We compute the counterfactual Herfindahl-Hirschman Index $(\mathrm{HHI})$ for each sector and aggregate them based on sectoral weights. We first compute the counterfactual sales if firms have had the same effective tax rate in 2017. The relative sales of large firms are shifted downward, which confirms that large firms benefit from the competitive edge offered by tax avoidance. We find that concentration would have been $8.3 \%$ lower in 2017 if firms have had the same effective tax rate. The value of the counterfactual $\mathrm{HHI}$ corresponds to its early 2000 level. In a second scenario, we substitute the 2017 audit probabilities for 1991's ones. We show that increasing the audit probabilities to their level in 1991 would have reduced concentration by $1.5 \%$. Eventually, we show the results remain robust and quantitatively meaningful if one controls for firms' R\&D activity. A conservative counterfactual scenario in which firms do not invest in R\&D still reveals a large effect 
of tax avoidance on concentration.

This paper makes several contributions to the literature. To the best of our knowledge, our paper is the first to analyze the impact of tax avoidance on industry concentration. Important contributions provide some explanation for the increase in concentration (Philippon, 2019). Some studies suggest increased concentration is driven by firms with high productivity gains. Autor et al. (2020) show the upward trend in concentration is due to the growth of superstar firms that are more productive. According to Crouzet and Eberly (2019), the increase in intangible capital is concentrated among industry leaders, and is thus closely related to the increase in industry concentration. By showing the impact of tax avoidance on sales is stronger for firms with a high share of intangibles, we offer an additional narrative for the key role of intangibles for concentration. Other studies show that increasing barriers to entry or lax or ineffective antitrust enforcement is also driving concentration (Gutiérrez and Philippon, 2018; Philippon, 2019). In this paper, we document that tax avoidance gives a competitive edge to large profit-shifting firms relative to smaller firms, leading to concentration.

Our results show that tax and competition policy are necessarily intertwined, as illustrated by the 2016 ruling of the European Commission, which found the Irish government distorted competition policy by giving Apple significant tax breaks. ${ }^{6}$ The case of Apple is not isolated. The European Commission took decisions against Luxembourg (for unlawful tax benefits presented to Fiat and Amazon) and the Netherlands (for illegal tax breaks given to Starbucks). ${ }^{7}$ The previously cited literature largely discusses the normative aspects of concentration, which is beyond the scope of this paper. Industry concentration may reflect market power or efficiency, with different implications for consumers' welfare (see Syverson, 2019, for a discussion). We show in this paper that this trend is

\footnotetext{
${ }^{6}$ According to Commissioner Margrethe Vestager, "Member States cannot give tax benefits to selected companies - this is illegal under EU state aid rules. The Commission's investigation concluded that Ireland granted illegal tax benefits to Apple, which enabled it to pay substantially less tax than other businesses over many years. In fact, this selective treatment allowed Apple to pay an effective corporate tax rate of 1 per cent on its European profits in 2003 down to 0.005 per cent in 2014" (The European Commission, 2016).

${ }^{7}$ See Hrushko (2017) for a detailed discussion of tax breaks and competition policy in the E.U.
} 
partly driven by aggressive tax-planning strategies that fall into the gray area, or that are illegal.

Our paper is also related to the literature documenting the increasing tax avoidance of corporations (Zucman, 2014; Dyreng et al., 2014). ${ }^{8}$ Some important papers in the accounting literature show that tax enforcement plays a tremendous role in curbing opportunities for tax avoidance (Hoopes, Mescall and Pittman, 2012; Nessa et al., 2020; De Simone, Stomberg and Williams, 2019). We confirm that larger U.S. firms undertake more aggressive tax positions as they face laxer tax enforcement. By giving a competitive advantage to larger firms, the laxer tax enforcement has real effects on the U.S. economy in terms of increasing concentration.

The rest of the paper is organized as follows. In section 2, we describes the firm-level data and the construction of our indicator of tax avoidance. In section 3, we present five facts on the evolution of concentration, tax avoidance and their interplay. In section 4, we presents a stylized model on the link between tax avoidance, sales, and concentration. We describe our empirical strategy in section 5. We show the results of our estimation of the impact of tax avoidance on individual sales and quantify the importance of tax avoidance for concentration in section 6 . We conclude in section 7 .

\section{Data}

Our primary datasource is Compustat, a database of firm-level financial information from S\&P Global Market Intelligence. Compustat provides partial coverage of the economy because it only includes large publicly traded firms. However, several papers have shown this subsample of the economy tracks relatively well aggregate trends observed in comprehensive data such as the Census data. For instance, Covarrubias, Gutiérrez and Philippon (2020) show the increase in concentration is similar in Compustat and in Census data. The Compustat dataset is particularly suited to our analysis

\footnotetext{
${ }^{8}$ This trend is tightly linked to mounting evidence of profit shifting by multinational firms (Swenson, 2001; Bartelsman and Beetsma, 2003; Clausing, 2003; Bernard, Jensen and Schott, 2006; Desai and Hines Jr, 2002; Egger, Eggert and Winner, 2010; Dharmapala, 2014; Cristea and Nguyen, 2016; Davies et al., 2018; Bilicka, 2019).
} 
because it contains a wealth of financial information consolidated at the company level that are not available in the Census data, which are based on U.S. establishments.

Our empirical analysis focuses on firms headquartered in the U.S and excludes subsidiaries and the financial sector. The unbalanced dataset consists of 14,999 firms in 89 NAICS 3-digit industries over the 1991-2017 period. The dataset includes many different variables such as turnover, employment, domestic and foreign pre-tax income, as well as property, plant and equipment assets, and capital expenditures. The information on intangible assets includes acquired intangibles such as goodwill, blueprints, patents, and software. ${ }^{9}$ These variables are key in constructing the set of relevant controls at the firm-level that are used in the empirical analysis below. Some of the observations in the dataset are missing, which decreases the size of our estimation sample to 9,414 firms. However, it covers more than $94 \%$ of total yearly sales, on average, over the period 1991-2017.

Tax avoidance and the probability of IRS audit. The literature in accounting and finance uses different measures to analyze tax avoidance. The concept of tax avoidance is defined broadly as "tax planning activities that are legal, or that may fall into the gray area, as well as activities that are illegal. Thus, tax aggressive activities do not necessarily indicate that the firm has done anything improper" (Chen et al., 2010, pp. 41-42).

A widely used measure of tax avoidance is the cash effective tax rate (ETR) which is the average tax rate that a corporation pays on its pre-tax profits and is computed as the ratio of cash tax paid over pre-tax book income. The ETR is a broad measure that is interpreted in comparison with the statutory tax rate. For many reasons, the effective tax rate could deviate from the statutory tax rate. A low effective tax rate may be driven by tax sheltering, profit shifting, or tax credits (Hanlon

\footnotetext{
${ }^{9}$ As noted by Gutiérrez and Philippon (2017), internally created intangibles such as R\&D or advertising are expended on the income statement and almost never appear on the balance sheet.
} 
and Heitzman, 2010). We define the ETR of firm $i$ as:

$$
E T R_{i s}=\frac{T X P D_{i s}}{P I_{i s}}
$$

where $T X P D_{i s}$ is the cash tax paid and $P I_{i s}$ is the pre-tax income of firm $i$ over a period $\mathrm{s}$ of years. Given the volatility of cash ETR using annual data, and because the measure could include tax payments of the former period, $s$ corresponds to an arbitrary number of year (Dyreng, Hanlon and Maydew, 2008). This measure is therefore the sum of cash taxes paid over a long period of time, divided by the sum of pre-tax income over the same time period. It captures the ability of firms to keep their effective tax rate low over a longer period and is thus more informative.

Although long-run cash ETR solves many problems associated with annual ETR measures, it suffers from a selection bias when pre-tax income is negative, which is the case for about $35 \%$ of firm-year observations in our sample. Restricting to firms with positive income and cash tax paid may thus induce some selection issues.

Henry and Sansing (2018) propose an alternative measure that can be computed for firms reporting negative profits. Their measure tracks the deviation between the actual amount of taxes paid and the amount that would have been paid if the pre-tax financial income were taxed at the statutory rate. By computing a measure of the departure of cash tax payments from the statutory tax on book income and scaling by the market value of total assets, the measure avoids the negative-sign problem that occurs in ETR when pre-tax income is negative. The measure of tax avoidance based on Henry and Sansing (2018) can be computed as:

$$
H S_{i s}=\frac{T X P D_{i s}-\tau \times P I_{i s}}{M V_{i s}}
$$


where $\tau$ is the statutory tax rate and $M V_{i s}$ the market value of the firm $i$ over period $s$. As for the ETR measure, we measure long-run tax avoidance using the $H S_{i s}$ variable. In the regression analysis, we present the results using six-year periods to compute our measure of the long-run HS tax gap and check the robustness of our results using a longer period of eight years. A firm without tax preferences will have an HS-gap measure of zero. When the firm has a defavorable tax position, the value of cash tax paid is larger than the expected tax payment so that HS is positive. Firms that conduct aggressive tax-avoidance strategies have a value of cash tax paid that is smaller than the expected tax payment so that HS is be negative. The $H S$ measure solves the problems associated with the $E T R_{i s}$ variable because it eliminates the risk of data selection bias, because $M V_{i s}$ will always be positive and no observation needs to be dropped.

The ETR and HS-gap-measures proxy for a whole range of activities that reduce the tax burden. A legitimate concern is that these measures only capture differences in tax credits received by companies for activities such as $R \& D$, and have little to do with tax avoidance. In appendix 9 , we plot the cumulative distribution of the $H S$-gap for multinational companies that own affiliates in tax havens against the $H S$-gap of companies that do not. ${ }^{10}$ Figure 9.1 shows that multinationals with affiliates in tax havens have a consistently lower $H S$ gap than other multinationals. A Kolmogorov-Smirnov test rejects the null that the two distributions are identical $(\mathrm{P}$-values $<0.001)$. These differences are important. If all multinational had no presence in tax haven, there would be no shift. This finding suggests that the measure captures tax-avoidance activities well. As we show later, these measures of tax avoidance are positively determined by the IRS audit probability, which also suggests they carry information on tax avoidance. This evidence is in line with the findings of several accounting papers showing the ETR and $H S$-gap measures do capture aggressive tax-planning strategies of

\footnotetext{
${ }^{10}$ We use the dataset provided by Dyreng and Lindsey (2009) to identify U.S. multinational presence in tax-haven countries. The information is available for a subsample of 4,229 firms spanning the 1993-2014 period. For the tax haven list, we follow the definition of Hines and Rice (1994) to which we add the Netherlands. See Souillard (2020) for a discussion of the data.
} 
companies (see, e.g., Schwab, Stomberg and Xia, 2019).

As mentioned above, the empirical analysis also relies on publicly available data from the IRS to compute the likelihood that the firm will be subject to an IRS audit. The IRS discloses an aggregation of data in its annual Databook, which has been posted to the website of the IRS's Statistics of Income Division. We use data from various annual reports of the IRS since 1992. The data are available for eight asset-size groups. We compute the audit probability as the number of corporate tax return audits completed in the IRS's fiscal year $t$ for an IRS asset-size group, divided by the number of corporate tax returns received in the previous calendar year for the same IRS asset-size group.

Measuring concentration. We use the sectoral Herfindahl index $(\mathrm{HHI})$ and the aggregate market share of the top four firms within a sector as alternative measures of concentration. We define an industry as a NAICS 3-digit sector and show our descriptive results are robust using the E.U. KLEMS sector classification as an alternative definition of industry. To do so, we create a correspondence between KLEMS sectors and NAICS 3-digit sectors. The aggregate level of concentration is a weighted average of our sector-level measures. The sector weights are either computed using Compustat sectoral sales or KLEMS sectoral output data.

Other variables. The market share of U.S. firms does not solely depend on the ability of firms to conduct aggressive tax-planning strategies. Different explanations have been proposed to explain the increase in concentration (Philippon, 2019). We use the richness of information in the Compustat dataset to construct important controls in our empirical analysis. Some research suggests increased concentration is driven by firms with high productivity gains. Autor et al. (2020) show the upward trend in concentration is due to the growth of superstar firms that are more productive. We approximate the productivity of the firm as the ratio of total sales to total employment. According to Crouzet and Eberly (2019), the increase in intangible capital is concentrated among industry 
leaders, and are thus closely related to the increase in industry concentration that has taken place since the mid-2000s. We calculate the intensity of firms in intangible assets as the ratio of intangible assets to total assets. We also include two indicators that might explain the rise of concentration. We add a dummy-variable information on acquisitions and payout as additional left-hand-side variables. We also include a dummy variable that accounts for the firm's multinational status.

\section{Facts}

We document a set of five facts on the evolution of concentration, tax avoidance, and their interplay. We show that U.S. industries have become more concentrated and that corporate tax avoidance has increased, especially among the set of large firms. Importantly, this section shows that more concentrated industries exhibit a wider cross-firm dispersion in tax avoidance.

Fact 1. Concentration of market shares. Figure 1 shows the increase in concentration in the U.S. over the period 1990-2017. The left panel reports the evolution of the average $\mathrm{HHI}$, and the right panel reports the evolution of the share of the top four firms in sectoral sales.

- Table 1 about here -

The graphs display concentration measures computed with different aggregation schemes. Both panels confirm that concentration has increased steadily in the U.S. since the mid-1990s. This observation is in line with evidence reported in Gutiérrez and Philippon (2018) and Grullon, Larkin and Michaely (2019), among others.

Fact 2. Corporate tax avoidance across years and sectors. Figure 2 shows that over the 1990-2016 period, tax avoidance, either measured by the sectoral effective tax rate or the sectoral HS tax gap, increased. The solid line shows the effective tax rate was close to the statutory tax rate 
of $35 \%$ at the beginning of the period and then dropped to a low $22 \%$ at the end of the period. The effective tax rate surged during the 2008-crisis, fell back to its pre-crisis level in 2009 , and then kept declining until 2016. The dotted line represents the evolution of the HS tax gap. The measure was close to zero in the early 1990s, suggesting the amount of tax paid by U.S. listed firms was about the same as the amount predicted by their financial income and the statutory tax rate. The variable then decreased (with, again, a surge during the crisis), showing the amount of tax paid was consistently lower than expected across U.S. sectors.

\section{- Figure 2 about here -}

Figure 3 shows tax avoidance has increased across almost all sectors, but with different intensities. The two panels display the average avoidance either measured by the effective tax rate or by the HS tax gap in the early 1990s (1990-1994) and at the end of our sample (2014-2017). Both panels show that tax avoidance measured with this indicator was higher at the end than at the beginning of the sample. Some sectors have experienced more significant increases in avoidance (real estate, information, utilities) than others (retail, wholesale, or professional services).

- Figure 3 about here -

Fact 3. The granular origin of tax avoidance. The conjecture regarding the correlation between tax avoidance and concentration rests on the premise that large firms have had more aggressive tax-planning strategies than smaller firms, which has strengthened concentration. Figure 4 confirms this hypothesis.

- Figure 4 about here -

The figure contrasts the evolution of the effective tax rate (left panel) or the HS tax gap (right panel) of large firms with the ones of the population of listed firms. We use different definitions 
for large firms by considering the top 100 firms based on their sales, employment, or total assets. We can see the top 100 firms in terms of assets follow more aggressive tax-planning strategies, in particular at the end of the sample. The difference between the whole population and the top 100 firms in terms of employment or sales is less striking, especially if one considers the effective tax rate. Note here that the mitigated results with the ETR measure can be due to a selection effect because the effective tax rate is computed across firms with positive profits. If firms with negative profits avoid less taxes and are not evenly distributed in the firm-size distribution, excluding these firms may bias the relationships between tax avoidance and firms' sales.

Fact 4. Heterogeneous drop in IRS audit probabilities. The audit probabilities are an aggregation of data across firms within a class of assets that the IRS discloses in its annual Databook. Table 1 and Figure 6 show that the probability of IRS audit has dropped for the largest firms in the U.S., but has remained relatively constant for the smallest firms. The drop in the audit probability for the smallest firms reporting in the first IRS asset class between 1991 and 2017 is $0.8 \%$, whereas it is over $40 \%$ for the largest firms. As argued by Hoopes, Mescall and Pittman (2012), this drop is tightly linked to cuts in the budget of the IRS, and is likely exogenous to individual companies' decisions concerning tax planning. Hoopes, Mescall and Pittman (2012) show stricter IRS monitoring implies a higher effective tax rate. They further report that $72 \%$ of firms assess the probability of being audited when they make tax decisions.

- Table 1 and Figure 6 about here -

Facts 5. Corporate tax avoidance and concentration across firms within sectors. If all firms within a sector have either high or low levels of tax avoidance, such a scenario does not provide a competitive advantage for some of them. concentration might be fueled by a dispersion in the level of tax avoidance across firms. Figure 5 provides the coefficients obtained from two series of 
regressions. On the left panel, the median level of tax avoidance across firms within sectors (either measured by the effective tax rate or the HS tax gap) is regressed against sector-level concentration measures (either defined by the $\mathrm{HHI}$ or the share of the top four firms in the sector). The regression coefficients show no correlation between the level of tax avoidance and concentration. The right panel shows instead that the dispersion in tax avoidance is positively and significantly correlated with concentration, which holds true regardless of the measures of tax avoidance and concentration used.

- Figure 5 about here -

This result is consistent with the view that heterogeneity in the level of tax avoidance may give an advantage to some firms and contribute to concentration. For this mechanism to hold, the largest firms must have more aggressive tax-planning strategies than smaller firms. This condition can be checked by examining the link between tax avoidance and sales at the firm level.

\section{Theoretical framework}

We present a parsimonious model that illustrates how tax avoidance affects the sales of a firm. The model allows us to derive the main mechanism through which avoidance, modeled in a reducedform way, matters for concentration. In Appendix 10, we discuss the different micro-foundations consistent with our modeling.

From tax avoidance to sales premium. We consider a simple economy with a distribution of heterogeneous firms $i$. Firms' products are horizontally differentiated. Consumers have CES preferences with an elasticity of substitution $\sigma>1$, and total expenditure in sector $j$ is denoted $Y_{j}$. 
Demand for the variety supplied by firm $i$ at price $p_{i}$ in sector $j$ is

$$
d_{j}\left(p_{i} ; \mathcal{P}_{j}\right)=\frac{Y_{j} p_{i}^{-\sigma}}{\mathcal{P}_{j}^{1-\sigma}}
$$

where $\mathcal{P}_{j}$ is the price-index in sector $j: \mathcal{P}_{j}=\left(\sum_{1}^{N_{j}} p_{i}^{1-\sigma}\right)^{\frac{1}{1-\sigma}}$.

Firms produce $q_{i}$ units from a single input at price $w$ but differ in their productivity $\left(\varphi_{i}\right)$ as well as in their ability to reduce the pre-tax profits declared to tax authorities. We assume for simplicity that a firm is able to inflate its overall cost by $\beta_{i} \geq 1$ to decrease the profits subject to corporate taxation. ${ }^{11}$ A firm's total profits after taxes can be written as:

$$
\pi_{i j}=\left(p_{i}-\frac{w}{\varphi_{i}}\right) q_{i}-t\left(p_{i}-\frac{w}{\varphi_{i}} \beta_{i}\right) q_{i}
$$

where $t$ is the statutory tax rate.

This reduced-form modeling of tax avoidance is consistent with firms manipulating the value of intrafirm transactions (transfer-pricing) to shift their tax base to low-tax jurisdictions. For instance, a firm may inflate its cost by importing an affiliate located in a tax haven a good priced beyond its "arm's length" value. ${ }^{12}$

Rearranging equation (4), this formulation captures that tax avoidance gives a competitive edge to a profit-shifting firm:

\footnotetext{
${ }^{11}$ Absent tax avoidance, it's commonplace to assume instead that firms can only deduct a share of their cost in which case $\beta<1$, which raises their effective marginal cost. Tax avoidance here distorts production in the other direction and acts as a subsidy. Our formulation of tax avoidance can be seen as a reduced form of Egger, Merlo and Wamser (2014).

${ }^{12}$ Symmetrically, we could have assumed that a firm deflates its export prices so that equation (4) becomes $\pi_{i j}=$ $\left(p_{i}-\frac{w}{\varphi_{i}}\right) q_{i}-t\left(\frac{p_{i}}{\beta_{i}}-\frac{w}{\varphi_{i}}\right) q_{i}$.
} 


$$
\pi_{i j}=(1-t)\left(p_{i}-\frac{w}{\varphi_{i}} \frac{1-\beta_{i} t}{1-t}\right) q_{i}
$$

Indeed, the above equation shows that by decreasing their tax base subject to the statutory rate $t$, firms decrease their effective marginal cost: $\frac{w}{\varphi_{i}} \frac{1-\beta_{i} t}{1-t}<\frac{w}{\varphi_{i}}$. This reduction in the marginal cost can also be micro-founded with a firm locating its intangible in a tax haven. Indeed, a firm may inflate the deductible share of its investment by importing high-valued services from an affiliate where its intangible assets are located, which in turn, can increase its investment and decrease its marginal cost of production. ${ }^{13}$

Note the $\beta$ parameter captures tax avoidance in a meaningful way. Indeed, absent tax credits and tax deferrals, tax avoidance can be measured by the wedge between the effective average and the statutory tax rates. We denote this gap for firm $i$ by Avoid $i_{i}$ :

$$
\text { Avoid }_{i}=t-t \frac{\left(p_{i}-\beta_{i} \frac{w}{\varphi_{i}}\right) q_{i}}{\left(p_{i}-\frac{w}{\varphi_{i}}\right) q_{i}}
$$

Denoting by $\mathcal{M}_{i}$ the markup charged over the firm's effective marginal cost of production, the above expression becomes

$$
\text { Avoid }_{i}=t\left(\frac{\beta_{i}-1}{\mathcal{M}_{i} \frac{1-\beta_{i} t}{1-t}-1}\right)
$$

Firms maximize their profits, given by (4), w.r.t. $p_{i}$ and subject to $q_{i}=d_{j}\left(p_{i} ; \mathcal{P}_{j}\right)$. When firms are price-index takers, monopolistically-competitive pricing (Spence, 1976) leads to a constant and equal mark-up for all firms $\mathcal{M}_{i}=\frac{\sigma}{\sigma-1}$. By (5), Avoid $i$ is then strictly decreasing in $\beta_{i}$. Consequently, a one-to-one correspondence exists between $\beta_{i}$ and the level of tax avoidance of firm $i^{14}$

\footnotetext{
${ }^{13}$ see Appendix A for the derivations of (4) in the presence of profit shifting through transfer pricing of goods or (intangible) services

${ }^{14}$ When large firms have both a higher markup and a higher $\beta$, equation (5) still holds but their effective tax rate is not necessarily lower than smaller firms. Tax avoidance will be larger for larger firms if the magnitude of shifted
} 
Using (3), we obtain Sales $_{i}=p_{i} \cdot d\left(p_{i}, \mathcal{P}_{j}\right)$ as a function of $\beta_{i}$. Firm sales then depend on the level of tax avoidance as follows:

$$
\text { Sales }_{i}=\mathcal{M}_{i}^{1-\sigma}\left(\frac{w}{\varphi_{i}} \frac{1-\beta_{i} t}{1-t}\right)^{1-\sigma} \mathcal{P}_{j}^{\sigma^{-}} Y_{j}
$$

From tax avoidance to concentration. It follows from equation (6) that, under monopolistically competitive pricing, the relative sales of any pair of firms $i$ and $i^{\prime}$ in the economy are given by

$$
\frac{\text { Sales }_{i}}{\text { Sales }_{i^{\prime}}}=\left(\frac{\varphi_{i}\left(1-\beta_{i^{\prime}} t\right)}{\varphi_{i^{\prime}}\left(1-\beta_{i} t\right)}\right)^{\sigma-1} .
$$

Equation (7) has two interesting implications. First, if all firms resort to the same level of tax avoidance $\left(\beta_{i}=\beta, \forall i\right)$, sales dispersion in the economy is entirely driven by differences in productivity, whatever the degree of tax avoidance. Instead, a dispersion in the degree of tax avoidance across firms contributes to sales dispersion.

Second, all else equal, an increase in tax aggressiveness by one firm with respect to another leads to an increase in its relative sales. Thus, if the largest firms in the economy tend to adopt relatively more aggressive tax-planning strategies, concentration increases. Formally, if we denote the $\mathrm{HHI}$ by $\mathcal{H}$, we have

$$
\mathcal{H}=\frac{\sum_{i=1}^{N_{j}} \text { Sales }_{i}^{2}}{\left(\sum_{i=1}^{N_{j}} \text { Sales }_{i}\right)^{2}} .
$$

We prove in the appendix that if firm $i$ engages relatively more into tax avoidance, i.e. $\beta_{i}$ increases

profits is large enough compared to its markup. For instance, it would be the case in the presence of strong increasing returns with respect to tax avoidance. Nevertheless, the impact of a change in tax avoidance on concentration holds under oligopoly as shown at the end of this section. 
relative to all other firms, then the $\mathrm{HHI}$ increases if and only if

$$
\mathcal{S}_{i}>\frac{\mathcal{H}_{-i}}{1+\mathcal{H}_{-i}}
$$

where $\mathcal{S}_{i}=\frac{\text { Sales }_{i}}{\sum_{i=1}^{N_{j}} \text { Sales }_{i}}$ denotes firm $i$ 's market share and $\mathcal{H}_{-i}=\frac{\sum_{i^{\prime}=1 ; i^{\prime} \neq i}^{N_{j}} \text { Sales }_{i^{\prime}}^{2}}{\left(\sum_{i^{\prime}=1 ; i^{\prime} \neq i}^{N_{j}} \text { Sales }_{i}\right)^{2}}$ is the hypothetical $\mathrm{HHI}$ in the absence of firm $i$. It is straightforward to see this condition is always verified for the largest firm and never verified for the smallest one. Generally, if tax avoidance is facilitated for a firm at the top of the distribution, concentration measured by the $\mathrm{HHI}$ will increase.

Oligopoly pricing. The closed-form results derived above rest on the assumptions of CES demand and monopolistically-competitive pricing. Accounting instead for oligopoly pricing implies that markups are no longer constant across firms: the markup $\mathcal{M}_{i}$ then becomes an increasing function of a firm's market share $\mathcal{M}_{i}=\mathcal{M}\left(\mathcal{S}_{i}\right) .{ }^{15}$ The characterization of an increase in concentration following more aggressive tax planning by a large firm remains true under oligopoly. Indeed, equation (6) still holds while equation (7) becomes

$$
\frac{\mathcal{S}_{i}}{\mathcal{S}_{i^{\prime}}}\left(\frac{\mathcal{M}\left(\mathcal{S}_{i}\right)}{\mathcal{M}\left(\mathcal{S}_{i^{\prime}}\right)}\right)^{\sigma-1}=\left(\frac{\varphi_{i}\left(1-\beta_{i^{\prime}} t\right)}{\varphi_{i^{\prime}}\left(1-\beta_{i} t\right)}\right)^{\sigma-1}
$$

Again, if the level of tax avoidance were the same across firms thent the distribution of market shares would not be distorted. By equation (8), an increase in tax avoidance for the largest firm would increase its relative sales and market shares, which would increase concentration as measured by the $\mathrm{HHI}$.

\footnotetext{
${ }^{15}$ For instance, under Cournot and Bertrand competition respectively, and absent Ford-effects, we get $\mathcal{M}\left(\mathcal{S}_{i}\right)=$ $\frac{1}{\rho\left(1-\mathcal{S}_{i}\right)}$ and $\mathcal{M}\left(\mathcal{S}_{i}\right)=\frac{1-\rho \mathcal{S}_{i}}{\rho\left(1-\mathcal{S}_{i}\right)}$ respectively, where $\rho=\frac{\sigma-1}{\sigma}$
} 


\section{Empirical Strategy}

In this section we present the econometric specification and explain two strategies aimed at assessing the causal impact of tax avoidance on sales.

Econometric specification. Reported tax and profit data may have significant year-to-year variations. To have a neat picture of firms' behavior, we follow Dyreng, Hanlon and Maydew (2008) by measuring tax avoidance as the ability to pay a low amount of tax for a long period of time. Because many firms report negative pre-tax income, we use $H S_{i s}$ measure developed by Henry and Sansing (2018).

We estimate the following specification throughout the empirical analysis:

$$
\log \text { Sales }_{i k s}=\beta_{0}+\beta_{1} H S_{i s}+\mathcal{X}_{i s}^{\prime} \odot+\alpha_{k s}+u_{i k s}
$$

where the dependent variable refers to the log sales of firm's $i$ in sector $k$ in the last year of period $s$ - or the $(\log )$ average sales across years within each period in a robustness check. Our preferred specification takes the sales at the end of the period to limit the simultaneity between sales and tax avoidance. ${ }^{16}$ Given the definition of the tax-avoidance measure, $H S_{i s}$, a finding of $\beta_{1}<0$ would indicate tax avoidance is positively associated with larger sales.

$\mathcal{X}_{i s}$ is a vector of firm-level attributes and includes the firm's intensity in intangible assets and a measure of labor productivity. We define a set of two dummy variables. The first indicates whether the firm is a multinational company; that is, it reports foreign profits or foreign taxes. The

\footnotetext{
${ }^{16}$ This specification amounts to examining the impact of past tax avoidance on current sales. We show the results are robust if one considers the average sales over the period rather than the end-of-period sales.
} 
second indicates whether firms have used funds to acquire equity, assets, or goodwill or invested in a company.

We include a large set of sector $\times$ year fixed effects, $\alpha_{k s}$. The sector fixed effects account for a broad set of unobserved attributes of the activities at the sector level that might also explain the concentration of market shares. Foreign competition may have forced, for instance, some firms to merge in certain industries such as in the textile industry. Technological shocks may affect firms in different sectors differently. The sector $\times$ year specific effects capture all these factors. Our baseline model identifies the impact of corporate tax avoidance across firms within a sector. We also exploit the within-firm variation by including a set of specifications with firm-level fixed effects. We use firm fixed effects to control for a broad set of unobserved firm attributes that explain the differences in the levels of sales: the firm's ability to manage tax avoidance, its corporate and managerial practices with respect to tax avoidance, or its perception of the legal (tax) environment. By using firm fixed effects, we cannot identify the coefficient of the dummy variable that provides information on the multinational status of the firm, because it is perfectly collinear. In addition, the interpretation of an acquisition dummy variable is slightly different because we identify the incidence of acquisition. We define $u_{i k s}$ as the error term.

Instrumentation strategy. Estimation of equation (9) by least squares is unlikely to be consistent, because large firms are more likely to follow more aggressive tax-planning strategies than smaller firms. We use the audit probabilities disclosed by the IRS to build the instrument for our measure of corporate tax avoidance. The IRS annual Databooks inform on the average audit probability for each of eight asset classes across the 27 years. These probabilities are correlated to firms' size because the IRS purposely has a higher audit rate for larger companies. We compute a measure of audit probability that is orthogonal to size- and year-specific patterns. The residual audit probabilities are constructed using the residuals of a regression of disclosed probabilities on asset-class and year 
fixed-effects. The mechanical correlation between the raw audit probability and firm size is therefore broken. The residual of the audit probability regression captures the yearly fluctuations in audit probability that are specific to each asset-class. ${ }^{17}$ Our instrument is however firm and period specific. By construction, we take for each firm in each year its corresponding residual audit probability that we average over the period of six years in our baseline estimation - or eight years in a robustness check. The instrument varies across firms and periods because the assigned residuals may change within a period as firms change asset-class. The instrument is given by:

$$
A u d i t_{i s}^{a d j}=\sum_{t \in s} A u d i t_{g(s) t}^{a d j} / N_{t}
$$

where $A u d i t_{g(s) t}^{a d j}$ is the adjusted audit probability of firms in asset-size class $g$ and $N_{t}$ is the number of years $t$ in period $s{ }^{18}$

Our identification strategy rests on the assumptions that tax avoidance at the level of firms responds to changes in the audit rates, and that firms' size at the end of each period does not affect the average changes in audit probabilities across years within each period. The first assumption is likely to hold. The literature on tax enforcement predicts that, all else equal, a decrease in tax enforcement increases tax avoidance (Hoopes, Mescall and Pittman, 2012; Nessa et al., 2020). Different elements suggest the second assumption is also verified. Anecdotal evidence as well as more in-depth analysis in the accounting literature suggest that changes in audit probability are explained by the underfunding of the IRS. For instance, Nessa et al. (2020) show that IRS resources are positively correlated to audit probability and to the net revenue collected through tax enforcement. Importantly, cuts in the funding of the IRS were not mainly motivated by the tax-avoidance behavior of large firms. The reduction of the IRS enforcement budget were the results of Congress warfare between Democrats

\footnotetext{
${ }^{17}$ This is due to the inclusion of year fixed-effects in the regression.

${ }^{18}$ Note the within-sector and period correlation between our instrument and the raw audit probabilities is low at about $19 \%$.
} 
and Republicans. As reported by Kiel and Eisinger (2018), the Republican-controlled Senate in 1997 and 1998 held a series of dramatic hearings on alleged abuses by the IRS. ${ }^{19}$

We use both endogenous least squares (OLS) in the baseline regressions as well as a just-identified two-stage least-squares (2SLS) model.

Alternative identification strategy. As an alternative to assess the causal impact of tax avoidance on sales, we exploit the change in the reporting requirement of U.S. publicly listed firms that occurred in 1998. Prior to December 1998 and the implementation of the Statement of Financial Accounting Standards No. 131 (SFAS 131), geographic earnings, sales and assets were required to be disclosed by all public firms. After the implementation of SFAS 131, the financial reporting requirement to disclose geographic earnings by jurisdiction is no longer mandatory. The identification strategy relies on the comparison of tax avoidance and sales before and after the change in legislation, for firms exposed to the policy compared to firms that are not. ${ }^{20}$ The voluntary disclosure of geographic earnings by jurisdiction under SFAS 131 is likely to affect firms' tax planning strategy because they can conceal tax avoidance behavior (Herrmann and Thomas, 2000; Hope, Ma and Thomas, 2013; Sullivan, 2004).

We use the implementation of SFAS 131 as an exogenous treatment affecting firms' tax avoidance behavior. Hope, Ma and Thomas (2013) and Herrmann and Thomas (2000) report that most multinational firms choose to no longer disclose geographic earning information after 1998. Furthermore, it is clear that firms with foreign activities have been the most affected by this change. ${ }^{21}$ We thus

\footnotetext{
${ }^{19} \mathrm{~A}$ more recent reason for cutting the IRS funding is that the agency was chosen to monitor the Affordable Care Act. Instead, there were no cuts during the George W. Bush administration and tax collection increased over this period (and the audit probability of large firms remained flat), which political commentators explain by the fact that the IRS was not an object of dispute during this era.

${ }^{20}$ By design, this analysis focuses on two periods in the 90 s and early 2000 s. We therefore prefer the previous identification strategy that i) tracks changes in avoidance and in sales for the most recent years, and ii) allows us to control for firm fixed effects because we have more than 2 periods per firm.

${ }^{21} \mathrm{Hope}, \mathrm{Ma}$ and Thomas (2013) report that "non-disclosure of geographic earnings is not associated with differences
} 
posit that multinational firms are the group of the treated firms. We consider the sales and tax avoidance of U.S. listed firms over 6-year periods before and after the implementation of SFAS 131.

We use this experiment in two ways. First, we estimate a standard difference-in-difference equation in which sales are regressed on an indicator of the MNE status of the firm and her interaction with a dummy variable, which takes the value of one in the post SFAS 131 period. We expect the interaction term to have a positive impact on sales because the disclosure of geographic earnings is not required after the implementation of SFAS $131 .{ }^{22}$ Second, we use the interaction term as an instrument for tax avoidance in the 2SLS specification. Indeed, Hope, Ma and Thomas (2013) show that the change from mandatory to voluntary disclosure of geographic earnings in accordance with SFAS 131 led to increased tax avoidance for non-disclosing firms.

\section{Results}

\subsection{Baseline results.}

Table 2 shows the results of the OLS and 2SLS regressions. We include in each specification a set of sector- and period-specific effects to control for unobserved characteristics. We therefore identify the effect of each covariate using the variation in firm-level attributes across firms within sector and period. We also include firm fixed effects in some specifications. In this case, we use the variation of firm-level characteristics within firm to identify the effect of tax avoidance and other covariates. Abadie et al. (2017) argue that "if the sampling and assignment mechanisms are not clustered, one should not adjust the standard errors for clustering, irrespective of whether such an adjustment would change the standard errors". The sampling and assignment mechanisms are not clustered in our case, because the variables of interest are specific to firm and period as the dependent variable

in domestic effective tax rates but is associated with lower foreign effective tax rates", confirming that the reform impacted firms with foreign operations.

${ }^{22}$ Notice that the Post - SFAS131 dummy variable is perfectly collinear with the sector and year fixed effect. 
and our sample covers the universe of U.S. publicly listed firms. ${ }^{23}$ We thus report robust standard errors in all specifications and the Kleibergen-Paap F-tests when using 2SLS regressions. ${ }^{24}$ The statistics yield values larger than 15 in the model that uses sector $\times$ period-specific effects and the ones that include firm-specific effects. These findings suggest the regression estimator is unlikely to suffer from weak-instruments bias.

- Table 2 about here -

In column (1), we report the OLS results that include sector and period fixed effects. We find a negative impact of the $H S_{i s}$ measure on firm-level sales, which suggests a positive impact of tax avoidance on sales. This effect is significant at the $99 \%$ confidence level. The other covariates have the expected signs and are highly significant at conventional levels. Firms with a larger share of intangibles and higher workforce productivity have larger sales. These findings support the results of Crouzet and Eberly (2019) and Autor et al. (2020) that industry leaders are often firms that are very good at producing intangible assets and are highly productive. In line with the literature that looks at the performance of multinational firms, we find these firms have larger sales than purely domestic firms (Antràs and Yeaple, 2014). The acquisition dummy variable is also positive and highly significant. These results are robust to the inclusion of firm-specific effects in column (2) when we exploit the within-firm variation. ${ }^{25}$ In particular, we find an increase in tax avoidance by a firm positively affects her sales.

In columns (3) and (4), we report the results of the 2SLS estimations using sector and period fixed effects. Column (3) reports the first-stage results. We find a positive and highly significant impact

\footnotetext{
${ }^{23} \mathrm{Abadie}$ et al. (2017) view clustering as a design problem. It might be a sampling design issue if the sampling follows a two-stage process, where (i) a subset of clusters are randomly sampled and (ii) units are sampled randomly from the sampled clusters. Since our dataset covers the universe of US publicly listed firms, there is no such problem. It might also be an experimental design issue: clusters of units, rather than units, are assigned to treatment. Again, there is no such issue here as the tax avoidance variable is firm-period specific as the dependent variable (firm sales). ${ }^{24}$ In Table 11.1, we show the results hold if standard errors are clustered at the level of the firm.

${ }^{25}$ The loss of observations is due to singleton firms.
} 
of the residual audit probabilities on the HS tax gap ratio. This result is in line with Hoopes, Mescall and Pittman (2012) and Nessa et al. (2020) who show that U.S. firms undertake less aggressive tax positions when tax enforcement is stricter. As noted previously, the specification that includes sector and period fixed effects use the variation in the IRS's audit probabilities across firms within sector and period. This finding suggests the heterogeneous cuts in the IRS's audit probabilities have contributed to tax avoidance across firms within sector and period. The large value of the Kleibergen-Paap F-statistic (KP F-stat) confirms the strength of our instrument. ${ }^{26}$ In column (4), we report the second-stage results and show the causal impact of tax avoidance on firm-level sales. The coefficient of the $H S_{i s}$ measure is negative and highly significant. Overall, the result suggests the cut in the IRS audit probability that benefited large firms allows them to use this tax advantage to increase sales.

In columns (5) and (6), we estimate the 2SLS model by adding firm-specific effects. This model cannot be used to assess the effect of the multinational status of the firm on her sales in as much as the former is perfectly collinear with the fixed effects. We still find the reduction in the IRS audit probability significantly increases firm-level tax avoidance. Column (6) confirms the causal and positive impact of tax avoidance on firm-level sales. As clearly indicated by the first stage results across specifications, we find that the influences of the HS gap measure on firm-level sales go beyond legal tax breaks including loopholes, deductions, exemptions, or tax credits.

In Table 3, we reproduce the 2SLS model specifications in Table 2 by separating manufacturing and services firms using their NAICS 3-digit classification.

- Table 3 about here -

The first-stage results confirm the adjusted audit probability remains a strong predictor of tax

\footnotetext{
${ }^{26}$ The within-sector and -period correlation between the raw audit probabilities and the residuals is 0.19 . This finding suggests our instrument is not correlated with firm size.
} 
avoidance. Overall, the industry-specific analysis suggests the positive effect of tax avoidance on sales described above is important in the manufacturing and services industries. However, several differences exist regarding the determinants of tax avoidance and sales in both samples. Concerning the second-stage estimations, the measure of tax avoidance has a positive impact on sales, but its influence is weaker in the manufacturing sector than in services, and less precisely estimated for the sample of manufacturing firms in the 2SLS model that includes firm-level fixed effects. Interestingly, the share of intangibles does not statistically determine the level of tax avoidance in the manufacturing sector, whereas it remains a strong predictor in services.

The results so far do not provide information on the observable characteristics of firms that magnify or reduce the effect of tax avoidance on firm-level sales. We interact the $H S_{i s}$ measure of tax avoidance with each of the remaining firm-level attributes that enter the baseline OLS and 2SLS second-stage regressions. These attributes are interacted with the adjusted probabilities in the first-stage regressions. The results are reported in Table 4.

- Table 4 about here -

Our main results hold. We find that firms that largely benefited from the reduction in the IRS audit probability, and therefore intensified their aggressive tax-planning strategies, have increased their sales over the sample period. Overall, the second-stage results of the specification that uses sector and period fixed effects suggests the effect of tax avoidance is larger in multinational firms than in domestic firms. ${ }^{27}$ Exploiting the firm variation by using firm-specific effects, we find the effect of tax avoidance is larger in firms that increased their share of intangible assets. This finding offers a new channel through which the increase in intangibles among a few firms has increased concentration (Crouzet and Eberly, 2019).

\footnotetext{
${ }^{27}$ Notice the interaction term between the HS-gap variable and the MNE-status indicator cannot be identified when using firm fixed effects.
} 


\subsection{SFAS No. 131 - A quasi-experiment}

Table 5 presents the results of our alternative strategy to assess the causal impact of tax avoidance on sales. We show the results using both difference-in-difference and 2SLS estimations.

\section{- Table 5 about here -}

Each specification includes sector and year fixed effects. We also include firm fixed effects in the specifications shown in the three last columns. The difference-in-differences strategy consists of comparing the sales of multinational firms (the treated group) with the sales of domestic firms (the control group), before and after the implementation of SFAS131. The interaction between our treatment variable and the post reform dummy is positive and significant, which means firms that benefited from the change in legislation experienced an increase in their sales. This finding hold when using firm fixed effects.

The first stages of the 2SLS regressions use the HS gap measure of tax avoidance as a dependent variable. Whatever the set of fixed effects included in the regressions, we find negative and significant interaction coefficients, which confirm that multinational firms significantly increase their level of tax avoidance after SFAS 131. Consistent with Hope, Ma and Thomas (2013), this results shows SFAS 131 led to an increase in tax avoidance for firms reporting foreign earnings. The second stage results show a negative and significant impact of the instrumented measure of tax avoidance on sales. These results confirms the causal impact of tax avoidance on sales.

\subsection{Robustness tests}

To assess the reliability of our results, we propose several robustness tests. In Table 11.2, we extend to eight the number of years in each period. The results are similar to those reported in Table

2. The results confirm the reduction in the IRS audit probability has led firms to avoid corporate 
taxation and to increase sales.

In Table 11.3, we keep information on permanent firms that have positive sales in both the first and last period of our sample. We conduct, therefore, an analysis in long differences and perform a similar instrumentation strategy as presented in the baseline specifications. The lack of significance of the share of intangibles and the acquisition indicators in the first stage explain the lower KP first-stage statistic. The IRS audit probability remains a strong predictor of the change in firm-level tax avoidance. In particular, we find the long-run decrease in the IRS audit probability significantly increases firm-level tax avoidance. The second-stage results confirm a larger increase in sales for firms that are more aggressive in terms of their tax planning.

In the supplementary material, we propose other robustness tests. We change the definition of the dependent variable in Table 11.4. We define sales as the $(\log )$ average sales of firms across years in each period instead of taking the (log) sales of firms in the last year of the period. Almost $40 \%$ of the firms in the estimation sample are incorporated in Delaware. We drop the corresponding observations in Table 11.5 because these firms might be responsible for the effect found earlier in our baseline regressions. Our main results remain qualitatively similar across the sets of robustness tests.

\subsection{Quantification exercises}

The empirical analysis shows that aggressive tax planning spurs firm-level sales. As shown in section 4, this behavior leads to an increase in concentration as long as tax planning is biased toward large firms. We now show that this mechanism is quantitatively relevant.

First, we use our econometric model to compute the counterfactual sales in the absence of corporate tax avoidance, and then compute counterfactual concentration levels. Under this scenario, we compare the $\mathrm{HHI}$ computed from the predicted sales delivered by our econometric model with the 
counterfactual sales if one predicts sales from our model assuming no firm engages in tax avoidance ( $H S$ index is nil). On average, the sectoral $\mathrm{HHI}$ under this scenario drops by $8.3 \%$, which is about its early 2000 level. In 2001, the Herfindahl index was 8\% lower than in 2017 (see Figure 1). Whereas a full quantification of the impact of tax avoidance on concentration is beyond the scope of this paper, our estimates suggest tax avoidance had a meaningful effect on the granularity of the U.S. economy. We the use our estimates to evaluate how much an increase in the audit probability of the largest firms would reduce concentration. We assign to firms in 2016 the corresponding adjusted audit probability (our instrumental variable) of 1990 - based on their sales. We then predict individual sales in 2016 in this counterfactual scenario, and we compute the $\mathrm{HHI}$. The results show a stricter IRS monitoring of large firms such as the one implemented in the early 1990s would have reduced the $\mathrm{HHI}$ by $1.5 \%$ on average.

A comparison of both exercises suggests about a fifth of the impact of tax avoidance on concentration can be attributed to laxer IRS monitoring. The rest is likely due to a change in the technology of tax avoidance by large firms. We conjecture that communication technologies have facilitated aggressive tax planning. Furthermore, the changing nature of investments and the increasing share of intangibles has also eased the tax avoidance of the largest companies.

\subsection{Assessing the role of $R \& D$ activities}

It is legitimate to ask whether our results are driven by R\&D tax credits, which would lead to very different implications for corporate tax policy. To rule out this possibility, we compute the impact of tax avoidance on sales under the rather extreme scenario of no R\&D activity. We therefore mute the possibility for firms to alleviate their tax burden through tax credits, allowances and other forms of R\&D-related legal tax reliefs, as well as shifting their profits to foreign low-tax jurisdictions through $R \& D$. We also neutralize the complementarity between tax reliefs and $R \& D$ that occurs when firms engaging in aggressive tax planning end-up with a higher effective return on $R \& D$ and increase their 
investment and sales.

Information on R\&D expenditures is missing for about $40 \%$ of firms and observations in our baseline sample. We run the initial specifications and include the intensity in R\&D as an additional control on this smaller sample. We lag the $R \& D$ variable by one period as the effects of $R \& D$ on firm-level sales may not be contemporaneous. ${ }^{28}$ The results reported in Table 6 remain robust to the inclusion of this variable. As in section 6.4 , we mute all forms of tax avoidance and show that under this scenario concentration (measured by an $\mathrm{HHI}$ ) drops by about $5.8 \%$ in this smaller sample.

We then use the previous regression and predict the counterfactual impact of tax avoidance on sales by setting $R \& D$ activities to zero for all firms. By construction, the counterfactual dispersion in sales in the absence of $R \& D$ activity can not be due to the direct impact of $R \& D$ on sales, nor to its indirect impact through a lower effective tax base. On average, under this conservative specification, the sectoral $\mathrm{HHI}$ estimated in this scenario drops by $2.4 \%$, which is about $40 \%(2.4 / 5.8)$ of the full effect of tax avoidance. These results imply that differences in R\&D activities explain a modest fraction of the key role of tax avoidance uncovered in the paper.

\section{Conclusion}

We show the relative increase in tax avoidance by large corporations has contributed to the increase in concentration observed in the data since the 1990s. The positive trends in concentration and in tax avoidance have been documented separately so far. We present causal evidence on the link between tax avoidance and concentration. We find tax avoidance gives a competitive edge to large firms, which allows them to increases their sales relative to smaller firms. Incidentally, we show tax avoidance is closely tied to the use of intangibles, which offers an additional narrative for the key role of intangibles for concentration. Large firms' competitive advantage is partly explained by laxer

\footnotetext{
${ }^{28}$ Using contemporaneous R\&D expenses does not change the main results: an increase in tax avoidance positively affects sales. The coefficient of contemporaneous $R \& D$ variable is however not significant.
} 
tax enforcement, which has been favorable for larger firms in the U.S. since 1990. The effect of tax avoidance on economy-wide concentration is sizable, because the latter would have been $8.3 \%$ lower if no firm had been engaged in tax-avoidance strategies.

One important insight from our analysis is that (the enforcement of) corporate tax policy can curb concentration. This finding suggests competition policy may become less effective in the absence of coordinated tax policies. The analysis also highlights that beyond its impact on government revenues, corporate tax avoidance has strong implications on the granularity of our economies. 


\section{References}

Abadie, Alberto, Susan Athey, Guido W Imbens, and Jeffrey Wooldridge. 2017. "When should you adjust standard errors for clustering?" National Bureau of Economic Research.

Antràs, Pol, and Stephen R Yeaple. 2014. "Multinational firms and the structure of international trade." In Handbook of international economics. Vol. 4, 55-130. Elsevier.

Autor, David, David Dorn, Lawrence F Katz, Christina Patterson, and John Van Reenen. 2017. "Concentrating on the Fall of the Labor Share." American Economic Review, Paper \& Proceedings, 107(5): 180-85.

Autor, David, David Dorn, Lawrence F Katz, Christina Patterson, and John Van Reenen. 2020. "The fall of the labor share and the rise of superstar firms." The Quarterly Journal of Economics, 135(2): 645-709.

Bartelsman, Eric J, and Roel MWJ Beetsma. 2003. "Why pay more? Corporate tax avoidance through transfer pricing in OECD countries." Journal of Public Economics, 87(9): 2225-2252.

Bernard, Andrew B, J Bradford Jensen, and Peter K Schott. 2006. "Transfer pricing by US-based multinational firms." National Bureau of Economic Research.

Bilicka, Katarzyna Anna. 2019. "Comparing UK tax returns of foreign multinationals to matched domestic firms." American Economic Review, 109(8): 2921-53.

Blouin, Jennifer, and Leslie A Robinson. 2019. "Double counting accounting: How much profit of multinational enterprises is really in tax havens?" Available at SSRN.

Cai, Hongbin, and Qiao Liu. 2009. "Competition and corporate tax avoidance: Evidence from Chinese industrial firms." The Economic Journal, 119(537): 764-795.

Chen, Shuping, Xia Chen, Qiang Cheng, and Terry Shevlin. 2010. "Are family firms more tax aggressive than non-family firms?" Journal of Financial Economics, 95(1): 41-61. 
Clausing, Kimberly A. 2003. "Tax-motivated transfer pricing and US intrafirm trade prices." Journal of Public Economics, 87(9): 2207-2223.

Clausing, Kimberly A. 2016. "The effect of profit shifting on the corporate tax base in the United States and beyond." National Tax Journal, 69(4): 905-934.

Clausing, Kimberly A. 2020. "How Big is Profit Shifting?" Available at SSRN 3503091.

Covarrubias, Matias, Germán Gutiérrez, and Thomas Philippon. 2020. "From Good to Bad Concentration? US Industries over the past 30 years." NBER Macroeconomics Annual, 34(1): 146.

Cristea, Anca D, and Daniel X Nguyen. 2016. "Transfer pricing by multinational firms: New evidence from foreign firm ownerships." American Economic Journal: Economic Policy, 8(3): 170202.

Crouzet, Nicolas, and Janice C. Eberly. 2019. "Understanding Weak Capital Investment: the Role of Market Concentration and Intangibles." National Bureau of Economic Research, Inc NBER Working Papers 25869.

Davies, Ronald B., Julien Martin, Mathieu Parenti, and Farid Toubal. 2018. "Knocking on Tax Haven's Door: Multinational Firms and Transfer Pricing." The Review of Economics and Statistics, 100(1): 120-134.

De Loecker, Jan, Jan Eeckhout, and Gabriel Unger. 2020. "The Rise of Market Power and the Macroeconomic Implications*." The Quarterly Journal of Economics, 135(2): 561-644.

Desai, Mihir A, and James R Hines Jr. 2002. "Expectations and Expatriations: Tracing the Causes and Consequences of Corporate Inversions." National Tax Journal, 409-440.

De Simone, Lisa, Bridget Stomberg, and Brian Williams. 2019. "Does Tax Enforcement Disparately Affect Domestic versus Multinational Corporations Around the World?" Kelley School of Business Research Paper 18-68. 
Dharmapala, Dhammika. 2014. "What do we know about base erosion and profit shifting? A review of the empirical literature." Fiscal Studies, 35(4): 421-448.

Dyreng, Scott D, and Bradley P Lindsey. 2009. "Using financial accounting data to examine the effect of foreign operations located in tax havens and other countries on US multinational firms' tax rates." Journal of Accounting Research, 47(5): 1283-1316.

Dyreng, Scott D, Michelle Hanlon, and Edward L Maydew. 2008. "Long-run corporate tax avoidance." The Accounting Review, 83(1): 61-82.

Dyreng, Scott D, Michelle Hanlon, Edward L Maydew, and Jacob R Thornock. 2014. "Changes in corporate effective tax rates over the past twenty-five years." Vol. 107, 1-58.

Egger, Peter H., Valeria Merlo, and Georg Wamser. 2014. "Unobserved tax avoidance and the tax elasticity of FDI." Journal of Economic Behavior \& Organization, 108: 1 - 18.

Egger, Peter, Wolfgang Eggert, and Hannes Winner. 2010. "Saving taxes through foreign plant ownership." Journal of International Economics, 81(1): 99-108.

Furman, Jason, and Peter Orszag. 2015. "A firm-level perspective on the role of rents in the rise in inequality." Presentation at "A Just Society" Centennial Event in Honor of Joseph Stiglitz Columbia University, 16.

Gabaix, Xavier. 2011. "The Granular Origins of Aggregate Fluctuations." Econometrica, 79(3): 733-772.

Grullon, Gustavo, Yelena Larkin, and Roni Michaely. 2019. "Are US industries becoming more concentrated?" Review of Finance, 23(4): 697-743.

Gumpert, Anna, James R. Hines, and Monika Schnitzer. 2016. "Multinational Firms and Tax Havens." The Review of Economics and Statistics, 98(4): 713-727.

Gutiérrez, Germán, and Thomas Philippon. 2017. "Declining Competition and Investment in the U.S." National Bureau of Economic Research Working Paper 23583. 
Gutiérrez, Germán, and Thomas Philippon. 2018. "Ownership, governance and investment." AEA Papers \& Proceedings, 108: 432-437.

Hanlon, Michelle, and Shane Heitzman. 2010. "A review of tax research." Journal of Accounting and Economics, 50(2): 127-178.

Henry, Erin, and Richard Sansing. 2018. "Corporate tax avoidance: data truncation and loss firms." Review of Accounting Studies, 23(3): 1042-1070.

Herrmann, Don, and Wayne B. Thomas. 2000. "An Analysis of Segment Disclosures under SFAS No. 131 and SFAS No. 14." Accounting Horizons, 14(3): 287-302.

Hines, James R, and Eric M Rice. 1994. "Fiscal paradise: Foreign tax havens and American business." The Quarterly Journal of Economics, 109(1): 149-182.

Hoopes, Jeffrey L, Devan Mescall, and Jeffrey A Pittman. 2012. "Do IRS audits deter corporate tax avoidance?" The Accounting Review, 87(5): 1603-1639.

Hope, Ole-Kristian, Mark (Shuai) Ma, and Wayne B. Thomas. 2013. "Tax avoidance and geographic earnings disclosure." Journal of Accounting and Economics, 56(2): 170 - 189.

Hrushko, Nina. 2017. "Tax in the World of Antitrust Enforcement: European Commission's State Aid Investigations into EU Member States' Tax Rulings." Brooklyn Journal of International Law, 43: 327.

Kiel, Paul, and Jesse Eisinger. 2018. "How the IRS Was Gutted." ProPublica.

Kubick, Thomas R, Daniel P Lynch, Michael A Mayberry, and Thomas C Omer. 2014. "Product market power and tax avoidance: Market leaders, mimicking strategies, and stock returns." The Accounting Review, 90(2): 675-702.

Nessa, Michelle, Casey M Schwab, Bridget Stomberg, and Erin M Towery. 2020. "How do IRS resources affect the corporate audit process?" The Accounting Review, 95(2): 311-338.

Philippon, Thomas. 2019. The Great Reversal: How America Gave Up on Free Markets. Harvard 
University Press.

Schwab, Casey M, Bridget Stomberg, and Junwei Xia. 2019. "Extreme ETRs: When Effective Tax Rates Capture Something Other than Tax Avoidance." Kelley School of Business Research Paper 18-92.

Shambaugh, Jay, Ryan Nunn, Audrey Breitwieser, and Patrick Liu. 2018. "The State of Competition and Dynamism: Facts about Concentration, Startups and Related Policies." Hamilton Project. Washington, DC: Brookings Institution.

Souillard, Baptiste. 2020. "Import competition and corporate tax avoidance: Evidence from the China shock." ECARES

Spence, Michael. 1976. "Product selection, fixed costs, and monopolistic competition." The Review of economic studies, 43(2): 217-235.

Sullivan, Martin. 2004. "Data show dramatic shift of profits to tax havens." Tax Notes, 13: 11901200.

Swenson, Deborah L. 2001. "Tax reforms and evidence of transfer pricing." National Tax Journal, $7-25$.

Syverson, Chad. 2019. "Macroeconomics and market power: Context, implications, and open questions." Journal of Economic Perspectives, 33(3): 23-43.

The European Commission. 2016. "State aid: Ireland gave illegal tax benefits to Apple worth up to 13 billion euros." European Commission.

Zingales, Luigi. 2017. "Towards a Political Theory of the Firm." Journal of Economic Perspectives, 31(3): 113-30.

Zucman, Gabriel. 2014. "Taxing across borders: Tracking personal wealth and corporate profits." The Journal of Economic Perspectives, 28(4): 121-148. 
Figure 1 - Evolution of concentration in the U.S. (1990-2017)

Herfindahl index

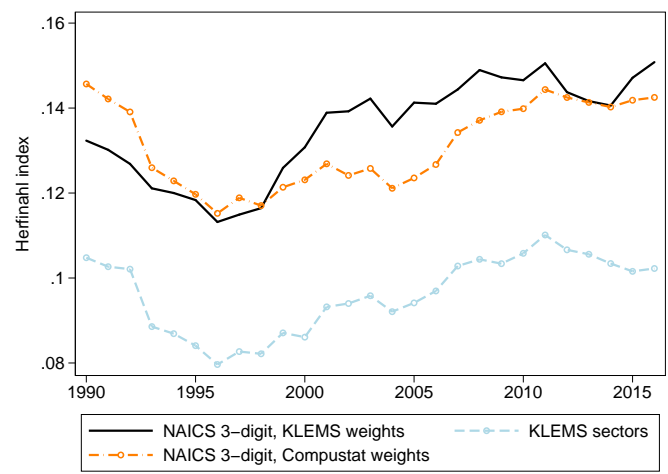

Share top 4 firms

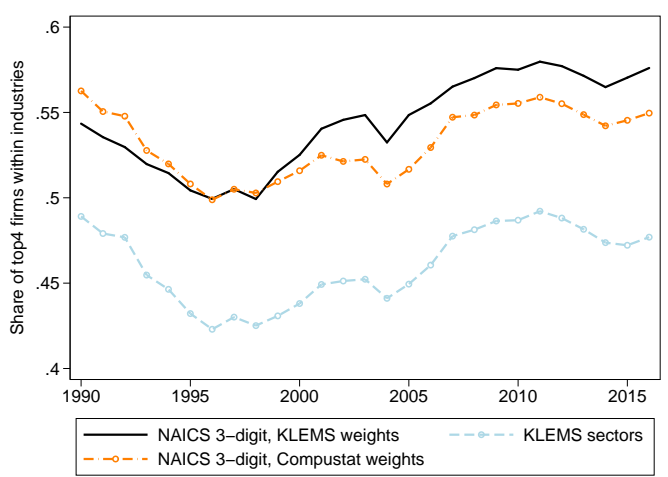

Notes: The HHI computed at the sectoral level and then aggregated. Share Top4 is the share of industry sales made up by the four largest firms. "NAICS 3-digit KLEMS weights": sector-level concentration computed using Compustat data at the NAICS 3-digit industry level and then weighted using KLEMS data. "NAICS 3-digit, Compustat weights": concentration computed using Compustat data at the NAICS 3-digit industry level and then weighted using Compustat sectoral sales. "KLEMS sectors" is a weighted average of HHI computed from Compustat at the level of KLEMS sector.

Figure 2 - Corporate tax avoidance in the U.S. (1990-2017)

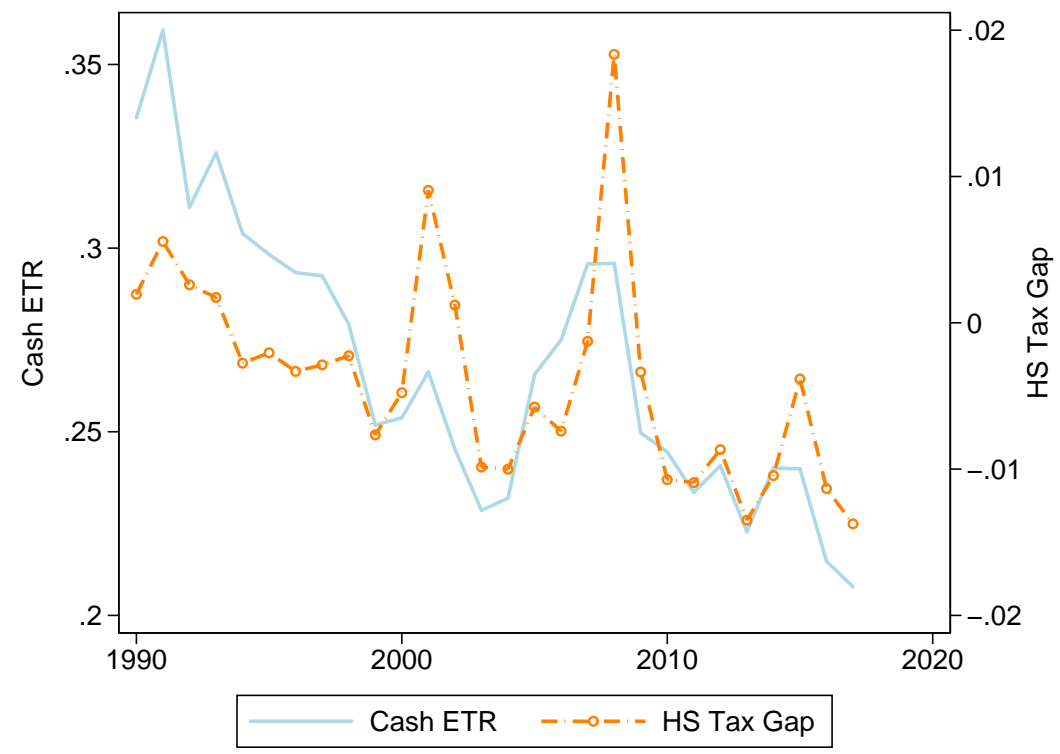

Notes: Weighted average of cash ETR and HS Tax Gap over time. Sample of U.S. incorporated companies, with assets greater than 5 millions USD, present at least 4 years in the data. Cash ETR computed as the ratio of cash tax paid to current pre-tax income for the sample of observations with positive sales, pre-tax income and cash-tax paid. HS Tax Gap computed as the difference between cash tax paid and $35 \% \times$ pretax income relative to total assets. 
Figure 3 - Tax avoidance across sectors

\section{Cash ETR}

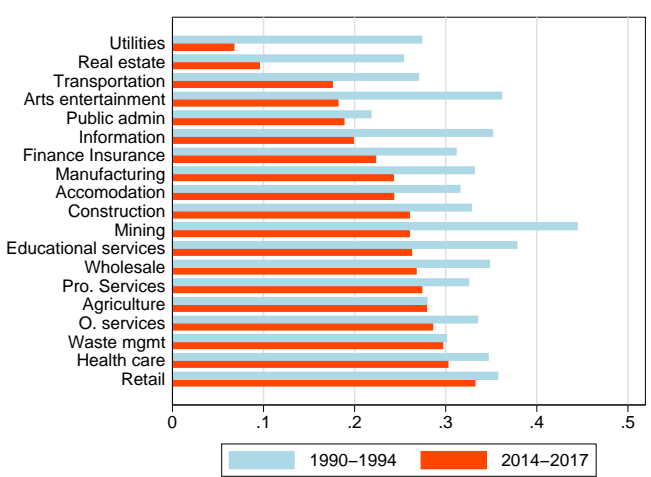

HS tax gap

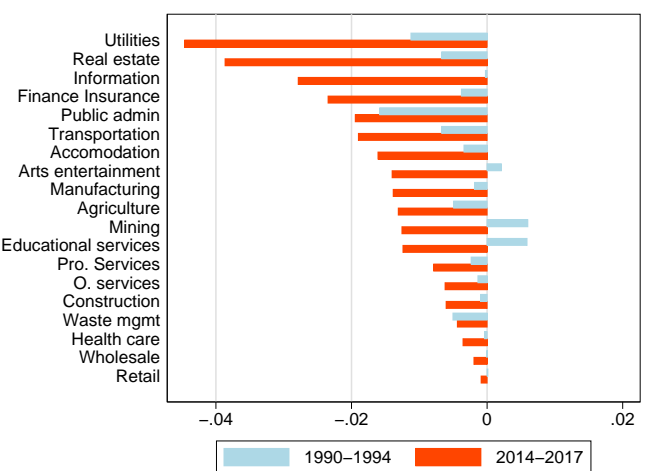

Notes: Sample of U.S. incorporated companies, with assets greater than five millions USD, present at least five years in the data. Cash ETR computed as the ratio of cash tax paid to current pre-tax income for the sample of observations with positive sales, pre-tax income, and cash-tax paid. HS Tax Gap computed as the difference between cash tax paid and $35 \% \times$ pretax income relative to total assets (computation includes firms with negative profits)

Figure 4 - Tax avoidance by top 100 firms

\section{Cash ETR}

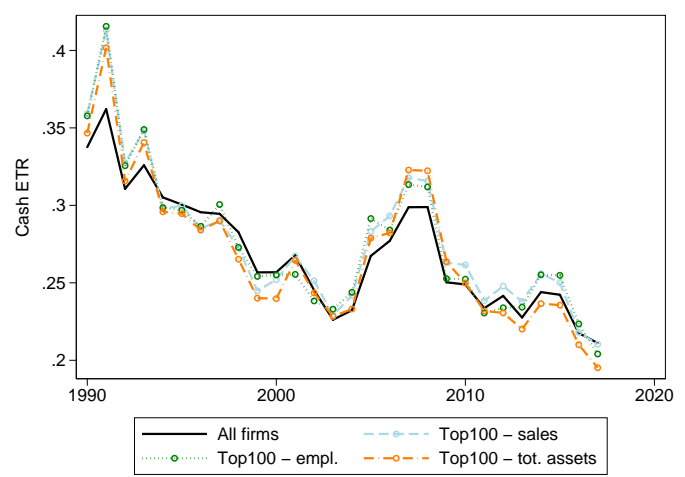

HS tax gap

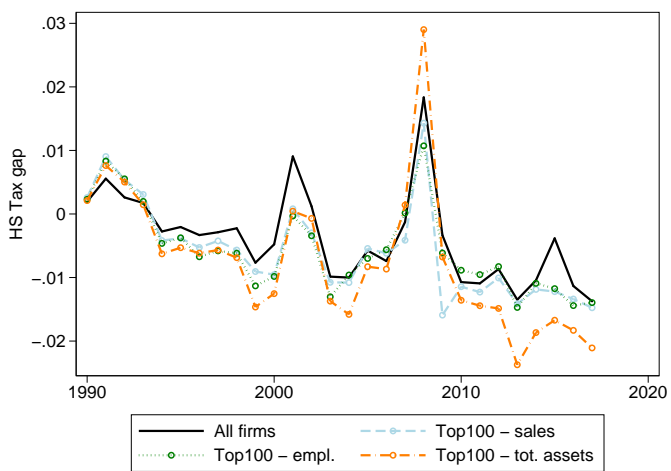

Notes: Top100 firms in terms of sales, employment, and total assets. Sample of U.S. incorporated companies, with assets greater than five millions USD, present at least five years in the data. Cash ETR computed as the ratio of cash tax paid to current pre-tax income for the sample of observations with positive sales, pre-tax income, and cash-tax paid. HS Tax Gap computed as the difference between cash tax paid and $35 \% \times$ pretax income relative to total assets (computation includes firms with negative profits). 
Figure 5 - Tax avoidance and concentration

Level

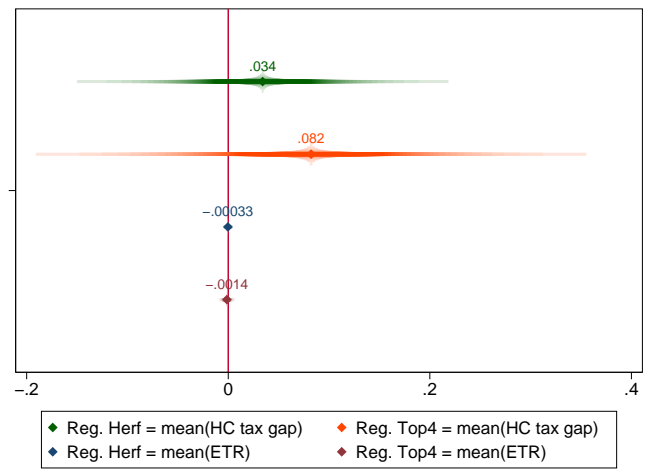

Dispersion

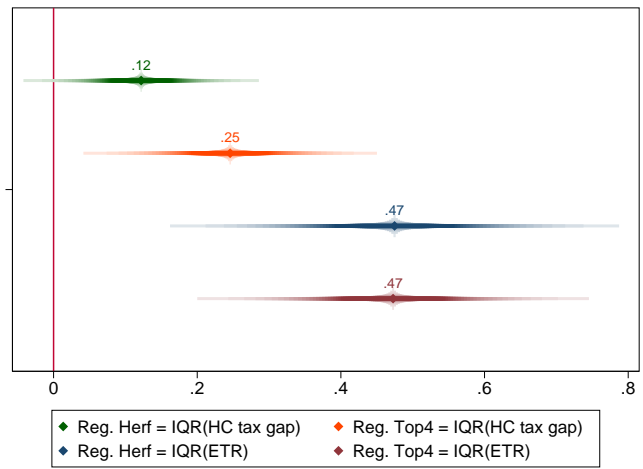

Note: Cash effective tax rates (ETR) and HS tax gaps are computed over four-year windows. On the left panel, regression of concentration against the level of effective tax rates by 3-digit NAICS industry and four-year periods (including period fixed effects). Concentration is measured by the $\mathrm{HHI}$ or the share of top4 firms in the industry. The level of the effective tax rate is the median across firms within a industry-period. On the right panel, regression of concentration against the dispersion of effective tax rates by 3-digit NAICS industry and four-year periods (including period fixed effects). Concentration is measured by the $\mathrm{HHI}$ or the share of top4 firms in the industry. Dispersion is measured by the interquartile range of our measures across firms within an industry-period.

Figure 6 - Probability of IRS audit, 1990-2017

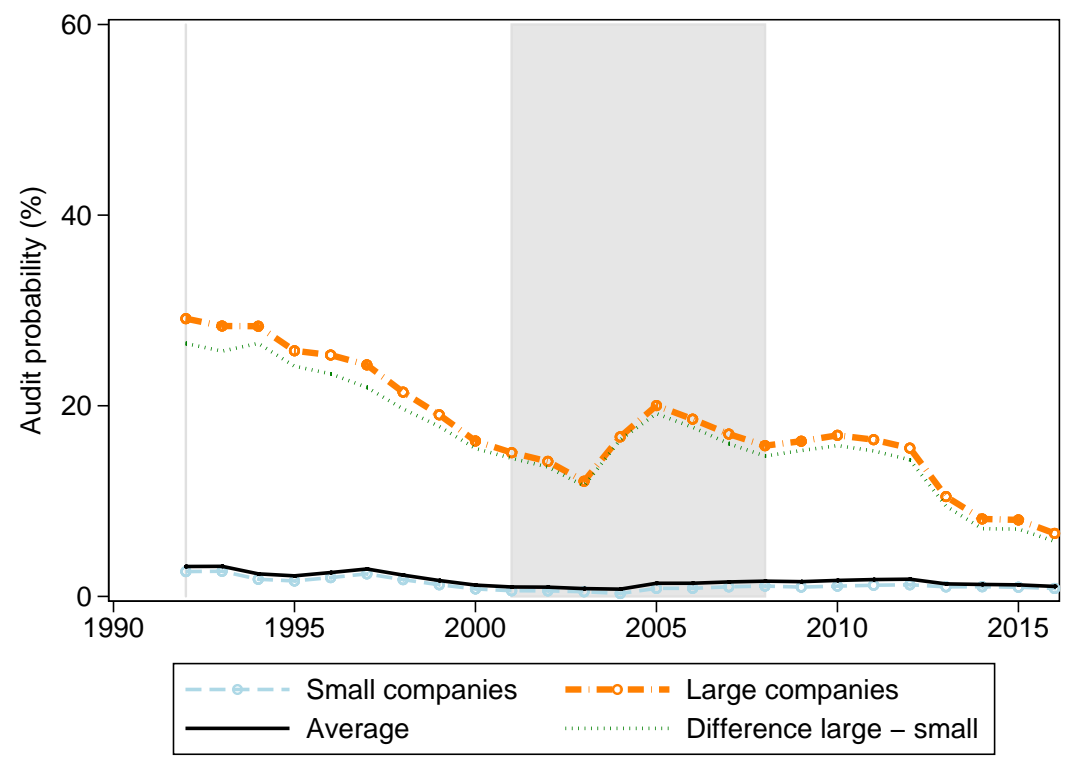

Notes:Probability to be audited by the IRS for U.S. companies. Small companies have assets below $10 \mathrm{M} \$$. Average probability is the weighted average across companies' class-sizes. The difference large - small is the difference in audit probability for large vs small companies. Grey area for years with a Republican U.S. president. 
Table 1 - Audit probabilities across assets group and years

\begin{tabular}{|c|c|c|c|}
\hline Asset class $g$ & Audit ${ }_{1991}^{g}$ & $A u d i t_{2017}^{g}$ & $\Delta$ Audit $_{17-91}^{g}$ \\
\hline 1 - Under $\$ 250,000$ & 1.23 & 0.40 & -0.8 \\
\hline $2-\$ 250,000$ under $\$ 1,000,000$ & 4.04 & 0.90 & -3.1 \\
\hline $3-\$ 1,000,000$ under $\$ 5,000,000$ & 10.04 & 0.80 & -9.2 \\
\hline $4-\$ 5,000,000$ under $\$ 10,000,000$ & 18.95 & 1.10 & -17.9 \\
\hline $5-\$ 10,000,000$ under $\$ 50,000,000$ & 23.34 & 4.60 & -18.7 \\
\hline $6-\$ 50,000,000$ under $\$ 100,000,000$ & 28.72 & 10.60 & -18.1 \\
\hline $7-\$ 100,000,000$ under $\$ 250,000,000$ & 31.29 & 9.70 & -21.6 \\
\hline $8-\$ 250,000,000$ or more & 56.09 & 14.06 & -42.0 \\
\hline
\end{tabular}

This table displays the audit probabilities for firms in specific IRS asset classes. The probabilities are the results of an aggregation of data across firm within a class of asset $g$ that the IRS discloses in its annual Databook. 
Table 2 - Sales and tax avoidance - OLS and 2SLS estimates

\begin{tabular}{|c|c|c|c|c|c|c|}
\hline \multirow[t]{3}{*}{ Dep. Variable } & \multicolumn{6}{|c|}{ Log Sales - End of Period } \\
\hline & \multicolumn{2}{|c|}{ OLS } & \multicolumn{4}{|c|}{$2 S L S$} \\
\hline & & & $1^{\text {st }}$ Stage & $2^{\text {nd }}$ Stage & $1^{\text {st }}$ Stage & $2^{\text {nd }}$ Stage \\
\hline HS tax gap & $\begin{array}{c}-2.00 * * * \\
(0.10)\end{array}$ & $\begin{array}{c}-0.72 * * * \\
(0.09)\end{array}$ & & $\begin{array}{c}-1.78 * * * \\
(0.31)\end{array}$ & & $\begin{array}{c}-1.45^{* * *} \\
(0.54)\end{array}$ \\
\hline Share of Intangible & $\begin{array}{c}1.43^{* * *} \\
(0.09)\end{array}$ & $\begin{array}{c}1.17^{* * *} \\
(0.09)\end{array}$ & $\begin{array}{c}-0.06 * * * \\
(0.02)\end{array}$ & $\begin{array}{c}1.45^{* * *} \\
(0.10)\end{array}$ & $\begin{array}{c}-0.09 * * * \\
(0.03)\end{array}$ & $\begin{array}{c}1.09 * * * \\
(0.12)\end{array}$ \\
\hline Labor Prod. & $\begin{array}{c}0.98 * * * \\
(0.02)\end{array}$ & $\begin{array}{c}0.68 * * * \\
(0.03)\end{array}$ & $\begin{array}{c}-0.09 * * * \\
(0.00)\end{array}$ & $\begin{array}{c}1.00 * * * \\
(0.04)\end{array}$ & $\begin{array}{c}-0.06^{* * *} \\
(0.01)\end{array}$ & $\begin{array}{c}0.64 * * * \\
(0.04)\end{array}$ \\
\hline Acquisition & $\begin{array}{c}1.16^{* * *} \\
(0.03)\end{array}$ & $\begin{array}{c}0.37^{* * *} \\
(0.02)\end{array}$ & $\begin{array}{c}-0.02 * * * \\
(0.00)\end{array}$ & $\begin{array}{c}1.16^{* * *} \\
(0.03)\end{array}$ & $\begin{array}{c}-0.02 * * * \\
(0.01)\end{array}$ & $\begin{array}{c}0.36 * * * \\
(0.02)\end{array}$ \\
\hline MNE Status & $\begin{array}{c}1.36^{* * *} \\
(0.03)\end{array}$ & & $\begin{array}{c}-0.08 * * * \\
(0.00)\end{array}$ & $\begin{array}{c}1.37^{* * *} \\
(0.04)\end{array}$ & & \\
\hline Audit Prob. (Adj.) & & & $\begin{array}{c}0.02 * * * \\
(0.00)\end{array}$ & & $\begin{array}{c}0.01^{* * *} \\
(0.00)\end{array}$ & \\
\hline Sector $\times$ Period FE & Yes & Yes & Yes & Yes & Yes & Yes \\
\hline Firm FE & No & Yes & No & No & Yes & Yes \\
\hline Obs. & 20,597 & 16,417 & 20,597 & 20,597 & 16,417 & 16,417 \\
\hline Number of Firms & 9414 & 5236 & 9414 & 9414 & 5236 & 5236 \\
\hline Adj. $R^{2}$ & 0.569 & 0.919 & 0.199 & & 0.575 & \\
\hline KP F-stat. & & & & 152 & & 32.38 \\
\hline
\end{tabular}

The dependent variable is the firm's log sales at the end of the six-year window. OLS and 2LS estimates with robust standard errors in parentheses. First stage Kleibergen-Paap rk Wald F statistic reported. ${ }^{* * *}$, **, and ${ }^{*}$ significantly different from 0 at the $1 \%, 5 \%$, and $10 \%$ confidence levels, respectively. 
Table 3 - Sales and tax avoidance - Across Sectors

\begin{tabular}{|c|c|c|c|c|c|c|c|c|}
\hline \multirow[t]{4}{*}{ Dep. Variable } & \multicolumn{8}{|c|}{ Log Sales - End of Period } \\
\hline & \multicolumn{8}{|c|}{$2 S L S$} \\
\hline & \multicolumn{4}{|c|}{ Manufacturing } & \multicolumn{4}{|c|}{ Services } \\
\hline & $1^{\text {st }}$ Stage & $2^{\text {nd }}$ Stage & $1^{\text {st }}$ Stage & $2^{\text {nd }}$ Stage & $1^{\text {st }}$ Stage & $2^{\text {nd }}$ Stage & $1^{\text {st }}$ Stage & $2^{\text {nd }}$ Stage \\
\hline HS tax gap & & $\begin{array}{c}-1.79 * * * \\
(0.47)\end{array}$ & & $\begin{array}{l}-0.78 \\
(1.37)\end{array}$ & & $\begin{array}{c}-1.89 * * * \\
(0.40)\end{array}$ & & $\begin{array}{c}-1.46 * * * \\
(0.49)\end{array}$ \\
\hline Share of Intangible & $\begin{array}{l}-0.01 \\
(0.02)\end{array}$ & $\begin{array}{c}1.41 * * * \\
(0.14)\end{array}$ & $\begin{array}{l}-0.04 \\
(0.03)\end{array}$ & $\begin{array}{c}0.99 * * * \\
(0.15)\end{array}$ & $\begin{array}{c}-0.09 * * * \\
(0.02)\end{array}$ & $\begin{array}{c}1.43^{* * *} \\
(0.13)\end{array}$ & $\begin{array}{c}-0.14 * * * \\
(0.04)\end{array}$ & $\begin{array}{c}1.17 * * * \\
(0.16)\end{array}$ \\
\hline Labor Prod. & $\begin{array}{l}-0.11^{* * *} \\
(0.01)\end{array}$ & $\begin{array}{c}1.09 * * * \\
(0.06)\end{array}$ & $\begin{array}{c}-0.08 * * * \\
(0.01)\end{array}$ & $\begin{array}{c}0.73^{* * *} \\
(0.11)\end{array}$ & $\begin{array}{c}-0.09 * * * \\
(0.01)\end{array}$ & $\begin{array}{c}0.72 * * * \\
(0.05)\end{array}$ & $\begin{array}{c}-0.05^{* * *} \\
(0.01)\end{array}$ & $\begin{array}{c}0.52^{* * *} \\
(0.06)\end{array}$ \\
\hline Acquisition & $\begin{array}{l}-0.01^{*} \\
(0.01)\end{array}$ & $\begin{array}{c}1.21 * * * \\
(0.04)\end{array}$ & $\begin{array}{c}-0.02^{* *} \\
(0.01)\end{array}$ & $\begin{array}{c}0.40 * * * \\
(0.04)\end{array}$ & $\begin{array}{c}-0.04 * * * \\
(0.01)\end{array}$ & $\begin{array}{c}1.05 * * * \\
(0.05)\end{array}$ & $\begin{array}{c}-0.02 * * \\
(0.01)\end{array}$ & $\begin{array}{c}0.34 * * * \\
(0.04)\end{array}$ \\
\hline MNE Status & $\begin{array}{l}-0.09 * * * \\
(0.01)\end{array}$ & $\begin{array}{c}1.69 * * * \\
(0.06)\end{array}$ & & & $\begin{array}{c}-0.08 * * * \\
(0.01)\end{array}$ & $\begin{array}{c}1.18^{* * *} \\
(0.06)\end{array}$ & & \\
\hline Audit Prob. (Adj.) & $\begin{array}{l}0.01 * * * \\
(0.00)\end{array}$ & & $\begin{array}{c}0.00 * * * \\
(0.00)\end{array}$ & & $\begin{array}{c}0.02^{* * *} \\
(0.00)\end{array}$ & & $\begin{array}{c}0.01^{* * *} \\
(0.00)\end{array}$ & \\
\hline Sector $\times$ Period FE & Yes & Yes & Yes & Yes & Yes & Yes & Yes & Yes \\
\hline Firm FE & No & No & Yes & Yes & No & No & Yes & Yes \\
\hline Obs. & 9,610 & 9,610 & 7,942 & 7,942 & 9,235 & 9,235 & 7,038 & 7,038 \\
\hline Number of Firms & 4139 & 4139 & 2471 & 2471 & 4521 & 4521 & 2326 & 2326 \\
\hline Adj. $\mathrm{R}^{2}$ & 0.230 & & 0.594 & & 0.184 & & 0.570 & \\
\hline KP F-stat. & & 89.19 & & 7.152 & & 67.81 & & 24.86 \\
\hline
\end{tabular}

The dependent variable is the firm's log sales at the end of the six-year window. 2LS estimates with robust standard errors in parentheses. First stage Kleibergen-Paap rk Wald F statistic reported. ***, **, and * significantly different from 0 at the $1 \%, 5 \%$, and $10 \%$ confidence levels, respectively. 
Table 4 - Sales and Tax Avoidance - With Interaction Terms

\begin{tabular}{|c|c|c|c|c|c|c|}
\hline \multirow[t]{3}{*}{ Dep. Variable } & \multicolumn{6}{|c|}{ Log Sales - End of Period } \\
\hline & \multicolumn{2}{|c|}{ OLS } & \multicolumn{4}{|c|}{$2 S L S$} \\
\hline & & & $1^{\text {st }}$ Stage & $2^{n d}$ Stage & $1^{\text {st }}$ Stage & $2^{\text {nd }}$ Stage \\
\hline HS tax gap (centered) & $\begin{array}{c}-2.04 * * * \\
(0.18)\end{array}$ & $\begin{array}{c}-0.80 * * * \\
(0.13)\end{array}$ & & $\begin{array}{l}-1.31^{* *} \\
(0.65)\end{array}$ & & $\begin{array}{c}-1.49 * * \\
(0.71)\end{array}$ \\
\hline Share of Intangible (centered) & $\begin{array}{c}1.39 * * * \\
(0.09)\end{array}$ & $\begin{array}{c}1.14^{* * *} \\
(0.10)\end{array}$ & $\begin{array}{c}-0.02 * * \\
(0.01)\end{array}$ & $\begin{array}{c}1.41^{* * *} \\
(0.09)\end{array}$ & $\begin{array}{c}-0.05 * * * \\
(0.02)\end{array}$ & $\begin{array}{c}1.09 * * * \\
(0.11)\end{array}$ \\
\hline Labor Prod. (centered) & $\begin{array}{c}0.97 * * * \\
(0.02)\end{array}$ & $\begin{array}{c}0.68 * * * \\
(0.03)\end{array}$ & $\begin{array}{c}-0.02 * * * \\
(0.00)\end{array}$ & $\begin{array}{c}0.99 * * * \\
(0.02)\end{array}$ & $\begin{array}{l}-0.00 \\
(0.00)\end{array}$ & $\begin{array}{c}0.68 * * * \\
(0.03)\end{array}$ \\
\hline Acquisition & $\begin{array}{c}1.10^{* * *} \\
(0.03)\end{array}$ & $\begin{array}{c}0.37^{* * *} \\
(0.02)\end{array}$ & $\begin{array}{l}-0.00 \\
(0.00)\end{array}$ & $\begin{array}{c}1.11^{* * *} \\
(0.03)\end{array}$ & $\begin{array}{c}0.00 \\
(0.01)\end{array}$ & $\begin{array}{c}0.37 * * * \\
(0.02)\end{array}$ \\
\hline MNE Status & $\begin{array}{c}1.25^{* * *} \\
(0.04)\end{array}$ & & $\begin{array}{c}-0.02^{* *} \\
(0.01)\end{array}$ & $\begin{array}{c}1.26 * * * \\
(0.04)\end{array}$ & & \\
\hline \multicolumn{7}{|l|}{ Interacton with } \\
\hline - Share of Intangible & $\begin{array}{c}-1.29 * * \\
(0.61)\end{array}$ & $\begin{array}{c}-1.41^{* * *} \\
(0.38)\end{array}$ & $\begin{array}{c}-0.80 * * * \\
(0.15)\end{array}$ & $\begin{array}{l}-0.70 \\
(0.73)\end{array}$ & $\begin{array}{c}-1.04 * * * \\
(0.24)\end{array}$ & $\begin{array}{c}-2.11^{* *} \\
(0.83)\end{array}$ \\
\hline - Labor Prod. & $\begin{array}{c}-0.32 * * * \\
(0.07)\end{array}$ & $\begin{array}{l}-0.07 \\
(0.05)\end{array}$ & $\begin{array}{c}-0.24 * * * \\
(0.02)\end{array}$ & $\begin{array}{l}-0.14 \\
(0.17)\end{array}$ & $\begin{array}{c}-0.24 * * * \\
(0.03)\end{array}$ & $\begin{array}{l}-0.23 \\
(0.18)\end{array}$ \\
\hline - Acquisition & $\begin{array}{c}-0.62 * * * \\
(0.20)\end{array}$ & $\begin{array}{c}0.00 \\
(0.13)\end{array}$ & $\begin{array}{c}0.57 * * * \\
(0.05)\end{array}$ & $\begin{array}{c}-1.03^{* *} \\
(0.42)\end{array}$ & $\begin{array}{c}0.22 * * * \\
(0.08)\end{array}$ & $\begin{array}{c}0.15 \\
(0.22)\end{array}$ \\
\hline - MNE Status & $\begin{array}{c}-1.99 * * * \\
(0.49)\end{array}$ & $\begin{array}{c}-0.43^{* *} \\
(0.21)\end{array}$ & $\begin{array}{c}0.33 * * * \\
(0.09)\end{array}$ & $\begin{array}{c}-2.24 * * * \\
(0.57)\end{array}$ & $\begin{array}{c}0.44^{* * *} \\
(0.08)\end{array}$ & $\begin{array}{l}-0.12 \\
(0.37)\end{array}$ \\
\hline Audit Prob. (Adj.) & & & $\begin{array}{c}0.01^{* * *} \\
(0.00)\end{array}$ & & $\begin{array}{c}0.00^{* * * *} \\
(0.00)\end{array}$ & \\
\hline Sector $\times$ Period FE & Yes & Yes & Yes & Yes & Yes & Yes \\
\hline Firm FE & No & Yes & No & No & Yes & Yes \\
\hline Obs. & 20,597 & 16,417 & 20,597 & 20,597 & 16,417 & 16,417 \\
\hline Number of Firms & 9414 & 5236 & 9414 & 9414 & 5236 & 5236 \\
\hline Adj. $R^{2}$ & 0.579 & 0.919 & 0.751 & & 0.828 & \\
\hline KP F-stat. & & & & 93.61 & & 55.01 \\
\hline
\end{tabular}

The dependent variable is the firm's log sales at the end of the six-year window. OLS and 2SLS estimates with robust standard errors in parentheses. The share of intangibles, the labor productivity and the three dummy variables are interacted with the audit probability in the first stage and with the HS tax gap in the second. First stage Kleibergen-Paap rk Wald $\mathrm{F}$ statistic reported. ${ }^{* * *},{ }^{* *}$, and ${ }^{*}$ significantly different from 0 at the $1 \%, 5 \%$, and $10 \%$ confidence levels respectively. 
Table 5 - Sales and Tax Avoidance - The SFAS 131 Quasi-Experiment

\begin{tabular}{|c|c|c|c|c|c|c|}
\hline \multirow[t]{3}{*}{ Dep. Variable } & \multicolumn{6}{|c|}{ Log Sales - End of Period } \\
\hline & \multirow[t]{2}{*}{ Diff-in-Diff } & \multicolumn{2}{|c|}{$2 S L S$} & \multirow[t]{2}{*}{ Diff-in-Diff } & \multicolumn{2}{|c|}{$2 S L S$} \\
\hline & & $1^{\text {st }}$ Stage & $2^{\text {nd }}$ Stage & & $1^{\text {st }}$ Stage & $2^{\text {nd }}$ Stage \\
\hline HS tax gap & & & $\begin{array}{c}-4.65 * * * \\
(0.93)\end{array}$ & & & $\begin{array}{c}-8.72 * * * \\
(2.87)\end{array}$ \\
\hline Share of Intangible & $\begin{array}{c}1.64 * * * \\
(0.13)\end{array}$ & $\begin{array}{c}-0.03 * * \\
(0.01)\end{array}$ & $\begin{array}{c}1.51^{* * *} \\
(0.13)\end{array}$ & $\begin{array}{c}1.16^{* * *} \\
(0.20)\end{array}$ & $\begin{array}{l}-0.04 \\
(0.03)\end{array}$ & $\begin{array}{c}0.79 * * * \\
(0.30)\end{array}$ \\
\hline Labor Prod. & $\begin{array}{c}1.01^{* * *} \\
(0.03)\end{array}$ & $\begin{array}{c}-0.07^{* * *} \\
(0.00)\end{array}$ & $\begin{array}{c}0.70 * * * \\
(0.07)\end{array}$ & $\begin{array}{c}0.58^{* * *} \\
(0.06)\end{array}$ & $\begin{array}{c}-0.04^{* * *} \\
(0.01)\end{array}$ & $\begin{array}{l}0.26^{*} \\
(0.14)\end{array}$ \\
\hline Acquisition & $\begin{array}{c}1.12^{* * *} \\
(0.04)\end{array}$ & $\begin{array}{c}-0.02^{* * *} \\
(0.00)\end{array}$ & $\begin{array}{c}1.01^{* * *} \\
(0.04)\end{array}$ & $\begin{array}{c}0.29 * * * \\
(0.03)\end{array}$ & $\begin{array}{c}-0.01 * * * \\
(0.00)\end{array}$ & $\begin{array}{c}0.20 * * * \\
(0.05)\end{array}$ \\
\hline MNE Status & $\begin{array}{c}1.33^{* * *} \\
(0.05)\end{array}$ & $\begin{array}{c}-0.01 * * * \\
(0.00)\end{array}$ & $\begin{array}{c}1.27 * * * \\
(0.05)\end{array}$ & & & \\
\hline MNE $\times$ Post $-S F A S 131$ & $\begin{array}{c}0.34 * * * \\
(0.07)\end{array}$ & $\begin{array}{c}-0.07 * * * \\
(0.01)\end{array}$ & & $\begin{array}{c}0.14^{* * *} \\
(0.04)\end{array}$ & $\begin{array}{c}-0.02 * * * \\
(0.00)\end{array}$ & \\
\hline Sector $\times$ Period FE & Yes & Yes & Yes & Yes & Yes & Yes \\
\hline Firm FE & No & No & No & Yes & Yes & Yes \\
\hline Obs. & 11796 & 11796 & 11796 & 7322 & 7322 & 7322 \\
\hline Adj. $R^{2}$ & 0.480 & 0.185 & & 0.917 & 0.461 & \\
\hline KP F-stat. & & & 97.15 & & & 15.66 \\
\hline
\end{tabular}

The dependent variable is the firm's log sales at the end of the six-year window. There are two periods of analysis starting in 1993. OLS and 2SLS estimates with robust standard errors in parentheses. First stage Kleibergen-Paap rk Wald $\mathrm{F}$ statistic reported. ${ }^{* *},{ }^{* *}$, and ${ }^{*}$ significantly different from 0 at the $1 \%, 5 \%$, and $10 \%$ confidence levels respectively. 
Table 6 - Sales and Tax Avoidance - R\&D intensity (One Period Lag)

\begin{tabular}{|c|c|c|c|c|c|c|}
\hline \multirow[t]{3}{*}{ Dep. Variable } & \multicolumn{6}{|c|}{ Log Sales - End of Period } \\
\hline & \multicolumn{2}{|c|}{ OLS } & \multicolumn{4}{|c|}{$2 S L S$} \\
\hline & & & $1^{\text {st }}$ Stage & $2^{\text {nd }}$ Stage & $1^{\text {st }}$ Stage & $2^{\text {nd }}$ Stage \\
\hline HS tax gap & $\begin{array}{c}-2.45^{* * *} \\
(0.30)\end{array}$ & $\begin{array}{c}-1.01^{* * *} \\
(0.16)\end{array}$ & & $\begin{array}{c}-2.65 * * * \\
(0.93)\end{array}$ & & $\begin{array}{c}-2.90 * * \\
(1.21)\end{array}$ \\
\hline Share of Intangible & $\begin{array}{c}1.60 * * * \\
(0.14)\end{array}$ & $\begin{array}{c}1.17^{* * *} \\
(0.13)\end{array}$ & $\begin{array}{l}-0.01 \\
(0.02)\end{array}$ & $\begin{array}{c}1.60^{* * *} \\
(0.14)\end{array}$ & $\begin{array}{c}-0.05^{*} \\
(0.02)\end{array}$ & $\begin{array}{c}1.04 * * * \\
(0.15)\end{array}$ \\
\hline R\&D Intensity (Lag) & $\begin{array}{c}0.36 * * * \\
(0.09)\end{array}$ & $\begin{array}{c}-0.04 \\
(0.35)\end{array}$ & $\begin{array}{c}0.03^{* *} \\
(0.02)\end{array}$ & $\begin{array}{c}0.37^{* * *} \\
(0.09)\end{array}$ & $\begin{array}{c}-0.14 * * * \\
(0.05)\end{array}$ & $\begin{array}{c}-0.31 \\
(0.45)\end{array}$ \\
\hline Labor Prod. & $\begin{array}{c}1.09 * * * \\
(0.04)\end{array}$ & $\begin{array}{c}0.54 * * * \\
(0.06)\end{array}$ & $\begin{array}{c}-0.09 * * * \\
(0.01)\end{array}$ & $\begin{array}{c}1.07^{* * *} \\
(0.09)\end{array}$ & $\begin{array}{c}-0.08 * * * \\
(0.01)\end{array}$ & $\begin{array}{c}0.39 * * * \\
(0.11)\end{array}$ \\
\hline Acquisition & $\begin{array}{c}1.40 * * * \\
(0.05)\end{array}$ & $\begin{array}{c}0.31^{* * *} \\
(0.03)\end{array}$ & $\begin{array}{c}-0.03 * * * \\
(0.00)\end{array}$ & $\begin{array}{c}1.40 * * * \\
(0.05)\end{array}$ & $\begin{array}{c}-0.02 * * \\
(0.01)\end{array}$ & $\begin{array}{c}0.28 * * * \\
(0.04)\end{array}$ \\
\hline MNE Status & $\begin{array}{c}1.48 * * * \\
(0.05)\end{array}$ & & $\begin{array}{c}-0.05 * * * \\
(0.01)\end{array}$ & $\begin{array}{c}1.47^{* * *} \\
(0.07)\end{array}$ & & \\
\hline Audit Prob. (Adj.) & & & $\begin{array}{c}0.01^{* * *} \\
(0.00)\end{array}$ & & $\begin{array}{c}0.00 * * * \\
(0.00)\end{array}$ & \\
\hline Sector $\times$ Period FE & Yes & Yes & Yes & Yes & Yes & Yes \\
\hline Firm FE & No & Yes & No & No & Yes & Yes \\
\hline Obs. & 8524 & 6867 & 8524 & 8524 & 6867 & 6867 \\
\hline Number of firms & 3855 & 2208 & 3855 & 3855 & 2208 & 2208 \\
\hline Adj. $\mathrm{R}^{2}$ & 0.593 & 0.936 & 0.210 & & 0.536 & \\
\hline KP F-stat. & & & & 49.45 & & 11.05 \\
\hline
\end{tabular}

The dependent variable is the firm's log sales at the end of the six-year window. OLS and 2LS estimates with robust standard errors in parentheses. First stage Kleibergen-Paap rk Wald F statistic reported. ${ }^{* * *}$, ${ }^{* *}$, and ${ }^{*}$ significantly different from 0 at the $1 \%, 5 \%$, and $10 \%$ confidence levels respectively. 


\section{Appendix}

\section{HS gap and tax avoidance}

Figure 9.1 shows the cumulative distribution of the HS-gap measure for the group of MNEs present in tax haven and the group of MNEs that are not. The higher of the two line in the plot is the cumulative distribution function (cdf) of the HS-gap of multinationals that own affiliates in tax haven countries; the lower is the same for multinationals that have no affiliates in tax haven. That the cdf is higher is consistent with lower $H S-$ gap for multinationals that have affiliates in tax haven. This evidence supports the idea that our measure of tax avoidance capture firm's aggressive tax planning strategies.

Figure 9.1 - Cumulative distribution of the HS-gap measure across groups of MNEs

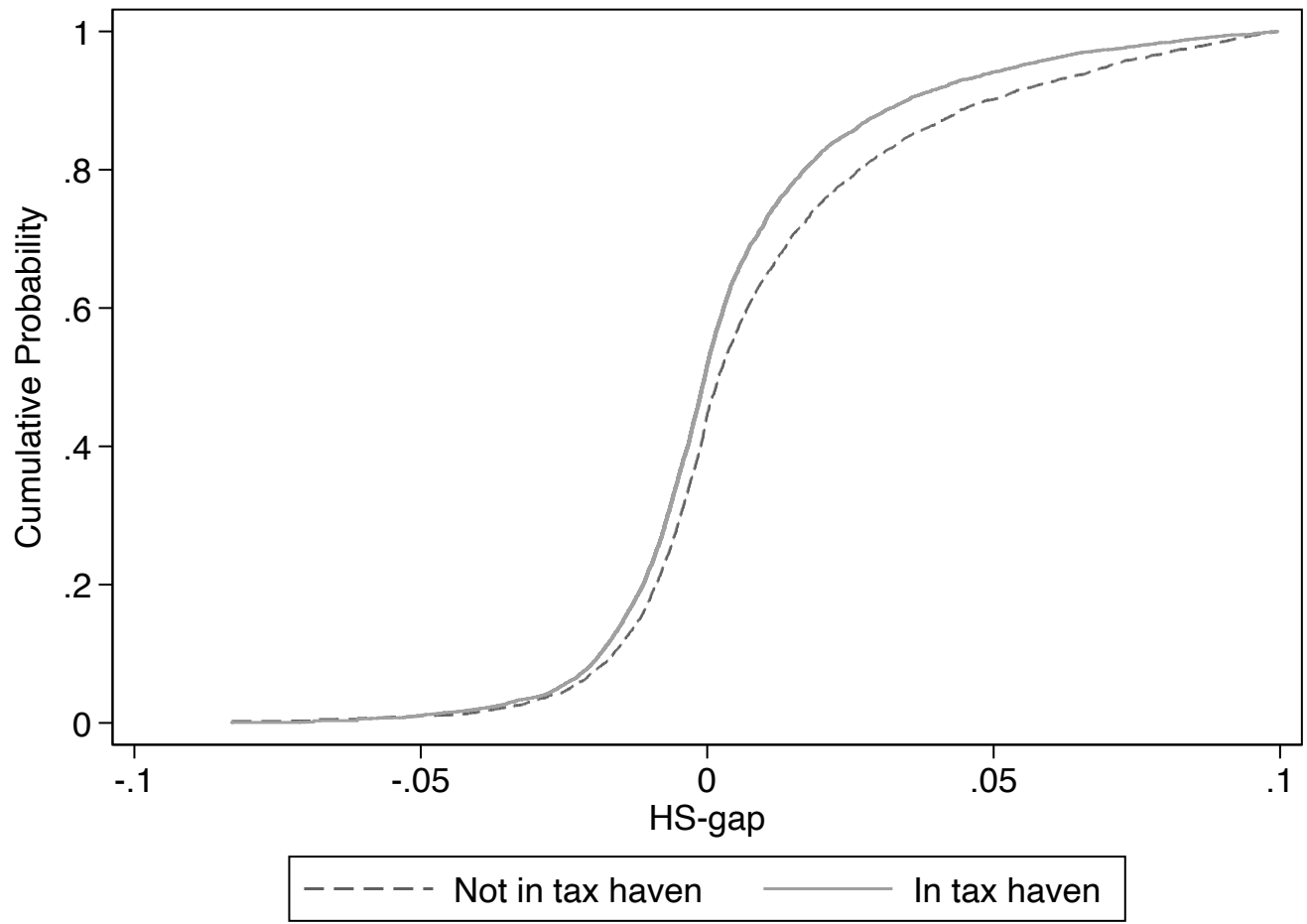

We use the Kolmogorov - Smirnov (KS-) test to determine if there are any differences in the 
distribution of HS gaps for the group of MNEs present in tax haven and the group of MNEs that are not. The KS-test statistic is computed as the largest vertical distance (D) between the two cdfs. We find a maximal distance of 0.1265 . This difference is computed to a null distribution in order to obtain the p-value for the test, which is 0.000 . It indicates overwhelming evidence of a difference between the two distributions. 


\section{Theory}

\section{A. Micro-founding tax avoidance}

This appendix presents three alternative micro-foundations for the $\beta_{i}$ parameter introduced in section 2.

Transfer pricing. A common practice that firms adopt to shift profits to a low-tax jurisdiction is to inflate the costs of inputs $\left(p^{I}\right)$ sourced from their affiliates in tax havens. If one assumes taxes are almost nil in tax havens; that is, $t^{H} \approx 0$, and inputs are produced there at almost no costs, firm profits then read:

$$
\pi_{i}=(1-t)\left(p_{i}-p^{I}-\frac{w}{\varphi_{i}}\right) q_{i}\left(p_{i}\right)+p^{I} q_{i}\left(p_{i}\right)\left(1-t^{H}\right)
$$

Simplifying, we get

$$
\pi_{i}=\left(p_{i}-\frac{w}{\varphi_{i}}\right) q_{i}\left(p_{i}\right)-t\left(p_{i}-\frac{w}{\varphi_{i}} \beta_{i}\right) q_{i}\left(p_{i}\right)
$$

where $\beta_{i} \equiv 1+\frac{p^{I} \varphi_{i}}{w}$.

If all firms were to set a price $p^{I}$ proportional to their marginal cost of production in the non-haven country; that is $p^{I} \propto \frac{w}{\varphi_{i}}$, then $\beta_{i}=\beta$ would be independent of firm productivity. Instead, if the price of the intangibles is the same for all firms, the cost inflator $\beta$ becomes positively related to firm productivity, which exacerbates concentration. Furthermore, if setting $p^{I}$ results from a trade-off between a lower effective tax rate and a concealment cost as in (Davies et al., 2018), large firms will typically deviate more from the arm's length price than small firms if they benefit from scale economies in their tax planning. A similar argument can be made if firms instead manipulate their export prices to foreign affiliates in tax havens downward. 
Intangibles as investment. Firms can invest in some intangible $f$ to decrease their marginal cost of production in the non-haven country by $f^{\alpha}$. We impose $\alpha<\frac{1}{\sigma-1}$ to guarantee an interior solution to the firm problem. The tax-deducted share of this investment is denoted $\gamma$. Absent profit-shifting motives, the investment is denoted $f_{0}$ and the firm's profits are given by

$$
\pi_{i}=\left(p_{i}-\frac{w}{\varphi_{i} f^{\alpha}}\right) q_{i}\left(p_{i}\right)-f_{0}-t\left(p_{i}-\frac{w}{\varphi f_{i}^{\alpha}}\right) q_{i}\left(p_{i}\right)+t \gamma f_{0}
$$

Now, assume the cost $f$ is borne in a tax haven in the form of the production of an intangible and that it may be imported at an inflated cost $\delta f>f$. The above equation becomes

$$
\pi_{i}=\left(p_{i}-\frac{w}{\varphi_{i} f^{\alpha}}\right) q_{i}\left(p_{i}\right)-f-t\left(p_{i}-\frac{w}{\varphi f_{i}^{\alpha}}\right) q_{i}\left(p_{i}\right)+t \delta \gamma f
$$

Denoting $\rho=\alpha(\sigma-1)<1$, the optimal investments with and without tax avoidance are given by

$$
\frac{f}{f_{0}}=\left(\frac{1-t \gamma}{1-t \gamma \delta}\right)^{\frac{1}{1-\rho}}>1
$$

In turn, the firm's marginal cost is reduced by $\left(\frac{1-t \gamma}{1-t \gamma \delta}\right)^{\frac{\alpha}{1-\rho}}$.

Setting

$$
\beta=\frac{1}{t}\left(1-(1-t)\left(\frac{1-t \gamma}{1-t \gamma \delta}\right)^{\frac{\alpha}{(1-\rho)(1-\sigma)}}\right)
$$

leads back to our baseline model.

\section{B. Tax-avoidance and concentration}

We denote by $s_{i}$ the sales of firm $i$. The Herfindahl is defined by

$$
\mathcal{H}=\frac{\sum_{i \leq N} s_{i}^{2}}{\left(\sum_{i \leq N} s_{i}\right)^{2}}
$$

where $N$ is the overall number of firms that we omit in the expressions below for the sake of clarity. 
Observing that $\mathcal{H}=1-\frac{2 \sum_{j \neq k} s_{k} s_{k}}{\left(\sum_{j} s_{j}\right)^{2}}$, differentiating the above expression w.r.t. $s_{k}$, that $\mathcal{H}$ increases with the sales of firm $i$ means that

$$
-\left(\sum_{j \neq i} s_{j}\right)\left(\sum_{j} s_{j}\right)+2\left(\sum_{j \neq k} s_{j} s_{k}\right)>0
$$

which can be rearranged as follows

$$
-\left(\sum_{j \neq i} s_{j}\right)^{2}+2\left(\sum_{j \neq k \neq i} s_{j} s_{k}\right)+s_{i}\left(\sum_{j \neq i} s_{j}\right)>0
$$

Introducing the Herfindahl index $\mathcal{H}_{-i}=\frac{\sum_{j \neq i} s_{j}^{2}}{\left(\sum_{j \neq i} s_{j}\right)^{2}}$ in the absence of firm $i$, we get

$$
\begin{gathered}
-\mathcal{H}_{-i}\left(\sum_{j \neq i} s_{j}\right)^{2}+s_{i}\left(\sum_{j \neq i} s_{j}\right)>0 \\
\frac{s_{i}}{\sum_{j} s_{j}}>\frac{\mathcal{H}_{-i}}{1+\mathcal{H}_{-i}}
\end{gathered}
$$

where $\frac{s_{i}}{\sum_{j} s_{j}}=\mathcal{S}_{i}$ is the market share of firm $i$. Whenever, tax avoidance increases the market share of a large firm i.e. such that the above inequality is satisfied, then the Herfindahl index increases. 


\section{Robustness tests}

Table 11.1 - Sales and tax avoidance - standard errors clustered at firm-level

\begin{tabular}{|c|c|c|c|c|c|c|}
\hline \multirow[t]{3}{*}{ Dep. Variable } & \multicolumn{6}{|c|}{ Log Sales - End of Period } \\
\hline & \multicolumn{2}{|c|}{ OLS } & \multicolumn{4}{|c|}{$2 S L S$} \\
\hline & & & $1^{\text {st }}$ Stage & $2^{\text {nd }}$ Stage & $1^{\text {st }}$ Stage & $2^{\text {nd }}$ Stage \\
\hline HS tax gap & $\begin{array}{c}-2.00 * * * \\
(0.11)\end{array}$ & $\begin{array}{c}-0.72 * * * \\
(0.09)\end{array}$ & & $\begin{array}{c}-1.78 * * * \\
(0.31)\end{array}$ & & $\begin{array}{c}-1.45^{* *} \\
(0.58)\end{array}$ \\
\hline Share of Intangible & $\begin{array}{c}1.43^{* * *} \\
(0.12)\end{array}$ & $\begin{array}{c}1.17^{* * *} \\
(0.10)\end{array}$ & $\begin{array}{c}-0.06 * * * \\
(0.02)\end{array}$ & $\begin{array}{c}1.45^{* * *} \\
(0.13)\end{array}$ & $\begin{array}{c}-0.09 * * * \\
(0.03)\end{array}$ & $\begin{array}{c}1.09 * * * \\
(0.12)\end{array}$ \\
\hline Labor Prod. & $\begin{array}{c}0.98 * * * \\
(0.03)\end{array}$ & $\begin{array}{c}0.68 * * * \\
(0.03)\end{array}$ & $\begin{array}{c}-0.09 * * * \\
(0.00)\end{array}$ & $\begin{array}{c}1.00 * * * \\
(0.04)\end{array}$ & $\begin{array}{c}-0.06^{* * * *} \\
(0.01)\end{array}$ & $\begin{array}{c}0.64^{* * *} \\
(0.05)\end{array}$ \\
\hline Acquisition & $\begin{array}{c}1.16^{* * *} \\
(0.04)\end{array}$ & $\begin{array}{c}0.37^{* * *} \\
(0.02)\end{array}$ & $\begin{array}{c}-0.02 * * * \\
(0.00)\end{array}$ & $\begin{array}{c}1.16 * * * \\
(0.04)\end{array}$ & $\begin{array}{c}-0.02 * * * \\
(0.01)\end{array}$ & $\begin{array}{c}0.36 * * * \\
(0.02)\end{array}$ \\
\hline MNE Status & $\begin{array}{c}1.36^{* * *} \\
(0.04)\end{array}$ & & $\begin{array}{c}-0.08 * * * \\
(0.01)\end{array}$ & $\begin{array}{c}1.37 * * * \\
(0.05)\end{array}$ & & \\
\hline Audit Prob. (Adj.) & & & $\begin{array}{c}0.02^{* * *} \\
(0.00)\end{array}$ & & $\begin{array}{c}0.01^{* * *} \\
(0.00)\end{array}$ & \\
\hline Sector $\times$ Period FE & Yes & Yes & Yes & Yes & Yes & Yes \\
\hline Firm FE & No & Yes & No & No & Yes & Yes \\
\hline Obs. & 20,597 & 16,417 & 20,597 & 20,597 & 16,417 & 16,417 \\
\hline Number of Firms & 9414 & 5236 & 9414 & 9414 & 5236 & 5236 \\
\hline Adj. $R^{2}$ & 0.569 & 0.919 & 0.199 & & 0.572 & \\
\hline KP F-stat. & & & & 129.3 & & 23.63 \\
\hline
\end{tabular}

The dependent variable is the firm's log sales at the end of the six-year window. OLS and 2LS estimates with robust standard errors clustered at firm-level in parentheses. First stage Kleibergen-Paap rk Wald $F$ statistic reported. ${ }^{* *},{ }^{* *}$, and ${ }^{*}$ significantly different from 0 at the $1 \%, 5 \%$, and $10 \%$ confidence levels, respectively. 
Table 11.2 - Sales and Tax Avoidance - eight-year window

\begin{tabular}{|c|c|c|c|c|c|c|}
\hline \multirow[t]{3}{*}{ Dep. Variable } & \multicolumn{6}{|c|}{ Log Sales - End of Period } \\
\hline & \multicolumn{2}{|c|}{ OLS } & \multicolumn{4}{|c|}{$2 S L S$} \\
\hline & & & $1^{\text {st }}$ Stage & $2^{\text {nd }}$ Stage & $1^{\text {st }}$ Stage & $2^{\text {nd }}$ Stage \\
\hline HS tax gap & $\begin{array}{c}-1.92^{* * *} \\
(0.11)\end{array}$ & $\begin{array}{c}-0.73^{* * *} \\
(0.10)\end{array}$ & & $\begin{array}{c}-3.15^{* * *} \\
(0.36)\end{array}$ & & $\begin{array}{c}-1.49 * * \\
(0.60)\end{array}$ \\
\hline Share of Intangible & $\begin{array}{c}1.46^{* * *} \\
(0.10)\end{array}$ & $\begin{array}{c}0.96 * * * \\
(0.11)\end{array}$ & $\begin{array}{c}-0.05^{* * *} \\
(0.02)\end{array}$ & $\begin{array}{c}1.36 * * * \\
(0.11)\end{array}$ & $\begin{array}{c}-0.09 * * * \\
(0.03)\end{array}$ & $\begin{array}{c}0.87^{* * *} \\
(0.14)\end{array}$ \\
\hline Labor Prod. & $\begin{array}{c}1.00 * * * \\
(0.02)\end{array}$ & $\begin{array}{c}0.69 * * * \\
(0.04)\end{array}$ & $\begin{array}{c}-0.09 * * * \\
(0.01)\end{array}$ & $\begin{array}{c}0.88 * * * \\
(0.04)\end{array}$ & $\begin{array}{c}-0.05^{* * *} \\
(0.01)\end{array}$ & $\begin{array}{c}0.65 * * * \\
(0.05)\end{array}$ \\
\hline Acquisition & $\begin{array}{c}1.19 * * * \\
(0.04)\end{array}$ & $\begin{array}{c}0.33 * * * \\
(0.03)\end{array}$ & $\begin{array}{c}-0.02 * * * \\
(0.01)\end{array}$ & $\begin{array}{c}1.16 * * * \\
(0.04)\end{array}$ & $\begin{array}{c}-0.01 \\
(0.01)\end{array}$ & $\begin{array}{c}0.32 * * * \\
(0.03)\end{array}$ \\
\hline MNE Status & $\begin{array}{c}1.38 * * * \\
(0.03)\end{array}$ & & $\begin{array}{c}-0.09 * * * \\
(0.01)\end{array}$ & $\begin{array}{c}1.27 * * * \\
(0.05)\end{array}$ & & \\
\hline Audit Prob. (Adj.) & & & $\begin{array}{c}0.02 * * * \\
(0.00)\end{array}$ & & $\begin{array}{c}0.01^{* * *} \\
(0.00)\end{array}$ & \\
\hline Sector $\times$ Period FE & Yes & Yes & Yes & Yes & Yes & Yes \\
\hline Firm FE & No & Yes & No & No & Yes & Yes \\
\hline Obs. & 16,168 & 11,843 & 16,168 & 16,168 & 11,843 & 11,843 \\
\hline Number of Firms & 8527 & 4205 & 8527 & 8527 & 4205 & 4205 \\
\hline Adj. $R^{2}$ & 0.572 & 0.919 & 0.201 & & 0.598 & \\
\hline KP F-stat. & & & & 127.4 & & 23.07 \\
\hline
\end{tabular}

The dependent variable is the firm's log sales at the end of the eight-year window. OLS and 2LS estimates with robust standard errors in parentheses. First stage Kleibergen-Paap rk Wald F statistic reported. ***, **, and ${ }^{*}$ significantly different from 0 at the $1 \%, 5 \%$, and $10 \%$ confidence levels, respectively. 
Table 11.3 - Sales and Tax Avoidance - Long Difference

\begin{tabular}{|c|c|c|c|}
\hline \multirow[t]{3}{*}{ Dep. Variable } & \multicolumn{3}{|c|}{$\Delta$ Log Sales - End of Period } \\
\hline & \multirow[t]{2}{*}{ OLS } & \multicolumn{2}{|c|}{$2 S L S$} \\
\hline & & $1^{\text {st }}$ Stage & $2^{\text {nd }}$ Stage \\
\hline$\Delta \mathrm{HS}$ tax gap & $\begin{array}{c}-1.88 * * * \\
(0.42)\end{array}$ & & $\begin{array}{c}-3.06 * * \\
(1.36)\end{array}$ \\
\hline$\Delta$ Share of Intangible & $\begin{array}{c}1.64 * * * \\
(0.23)\end{array}$ & $\begin{array}{l}-0.02 \\
(0.03)\end{array}$ & $\begin{array}{c}1.56^{* * *} \\
(0.26)\end{array}$ \\
\hline$\Delta$ Acquisition & $\begin{array}{c}0.07 \\
(0.08)\end{array}$ & $\begin{array}{c}0.02 \\
(0.02)\end{array}$ & $\begin{array}{c}0.10 \\
(0.09)\end{array}$ \\
\hline$\Delta$ Labor Prod. & $\begin{array}{c}0.56 * * * \\
(0.07)\end{array}$ & $\begin{array}{c}-0.05^{* * *} \\
(0.01)\end{array}$ & $\begin{array}{c}0.50 * * * \\
(0.09)\end{array}$ \\
\hline$\Delta$ Audit Prob. (Adj.) & & $\begin{array}{c}0.01^{* *} \\
(0.00)\end{array}$ & \\
\hline Sector FE & Yes & Yes & Yes \\
\hline Obs. & 1,339 & 1,339 & 1,339 \\
\hline Adj. $R^{2}$ & 0.280 & 0.0855 & \\
\hline KP F-stat. & & & 5.841 \\
\hline
\end{tabular}

The dependent variable is the firm's log sales at the end of the eight-year window. OLS and 2LS estimates with robust standard errors in parentheses. First stage Kleibergen-Paap rk Wald F statistic reported. ${ }^{* * *}$, **, and ${ }^{*}$ significantly different from 0 at the $1 \%, 5 \%$, and $10 \%$ confidence levels, respectively. 
Table 11.4 - Sales and Tax Avoidance - OLS and 2SLS estimates

\begin{tabular}{|c|c|c|c|c|c|c|}
\hline \multirow[t]{3}{*}{ Dep. Variable } & \multicolumn{6}{|c|}{ Log Sales - Average } \\
\hline & \multicolumn{2}{|c|}{ OLS } & \multicolumn{4}{|c|}{$2 S L S$} \\
\hline & & & $1^{\text {st }}$ Stage & $2^{\text {nd }}$ Stage & $1^{\text {st }}$ Stage & $2^{\text {nd }}$ Stage \\
\hline HS tax gap & $\begin{array}{c}-1.62 * * * \\
(0.06)\end{array}$ & $\begin{array}{c}-0.60 * * * \\
(0.04)\end{array}$ & & $\begin{array}{c}-1.05^{* * *} \\
(0.21)\end{array}$ & & $\begin{array}{c}-1.65^{* * *} \\
(0.26)\end{array}$ \\
\hline Share of Intangible & $\begin{array}{c}1.31^{* * *} \\
(0.07)\end{array}$ & $\begin{array}{c}0.97^{* * *} \\
(0.07)\end{array}$ & $\begin{array}{c}-0.11^{* * *} \\
(0.01)\end{array}$ & $\begin{array}{c}1.39 * * * \\
(0.08)\end{array}$ & $\begin{array}{c}-0.16 * * * \\
(0.03)\end{array}$ & $\begin{array}{c}0.78^{* * *} \\
(0.09)\end{array}$ \\
\hline Labor Prod. & $\begin{array}{c}0.98 * * * \\
(0.01)\end{array}$ & $\begin{array}{c}0.74^{* * *} \\
(0.02)\end{array}$ & $\begin{array}{c}-0.11^{* * *} \\
(0.00)\end{array}$ & $\begin{array}{c}1.04^{* * *} \\
(0.03)\end{array}$ & $\begin{array}{c}-0.08 * * * \\
(0.01)\end{array}$ & $\begin{array}{c}0.65^{* * *} \\
(0.03)\end{array}$ \\
\hline Acquisition & $\begin{array}{c}1.00 * * * \\
(0.02)\end{array}$ & $\begin{array}{c}0.29 * * * \\
(0.01)\end{array}$ & $\begin{array}{c}-0.03 * * * \\
(0.00)\end{array}$ & $\begin{array}{c}1.01^{* * *} \\
(0.02)\end{array}$ & $\begin{array}{c}-0.02 * * * \\
(0.00)\end{array}$ & $\begin{array}{c}0.27^{* * *} \\
(0.02)\end{array}$ \\
\hline MNE Status & $\begin{array}{c}1.32 * * * \\
(0.02)\end{array}$ & & $\begin{array}{c}-0.10 * * * \\
(0.00)\end{array}$ & $\begin{array}{c}1.38 * * * \\
(0.03)\end{array}$ & & \\
\hline Audit Prob. (Adj.) & & & $\begin{array}{c}0.02^{* * *} \\
(0.00)\end{array}$ & & $\begin{array}{c}0.01 * * * \\
(0.00)\end{array}$ & \\
\hline Sector $\times$ Period FE & Yes & Yes & Yes & Yes & Yes & Yes \\
\hline Firm FE & No & Yes & No & No & Yes & Yes \\
\hline Obs. & 26,088 & 22,189 & 26,088 & 26,088 & 22,189 & 22,189 \\
\hline Number of firms & 11457 & 7560 & 11457 & 11457 & 7560 & 7560 \\
\hline Adj. $\mathrm{R}^{2}$ & 0.591 & 0.939 & 0.218 & & 0.574 & \\
\hline KP F-stat. & & & & 226.8 & & 76.45 \\
\hline
\end{tabular}

The dependent variable is the logarithm of the firm's average sales across the six-year window. OLS and 2LS estimates with robust standard errors in parentheses. First stage Kleibergen-Paap rk Wald $F$ statistic reported. ${ }^{* *},{ }^{* *}$, and ${ }^{*}$ significantly different from 0 at the $1 \%, 5 \%$, and $10 \%$ confidence levels, respectively. 
Table 11.5 - Sales and Tax Avoidance - Without Delaware

\begin{tabular}{|c|c|c|c|c|c|c|}
\hline \multirow[t]{3}{*}{ Dep. Variable } & \multicolumn{6}{|c|}{ Log Sales - End of Period } \\
\hline & \multicolumn{2}{|c|}{ OLS } & \multicolumn{4}{|c|}{$2 S L S$} \\
\hline & & & $1^{\text {st }}$ Stage & $2^{\text {nd }}$ Stage & $1^{\text {st }}$ Stage & $2^{\text {nd }}$ Stage \\
\hline HS tax gap & $\begin{array}{c}-1.64 * * * \\
(0.11)\end{array}$ & $\begin{array}{c}-0.57^{* * *} \\
(0.12)\end{array}$ & & $\begin{array}{c}-1.94 * * * \\
(0.39)\end{array}$ & & $\begin{array}{c}-1.70^{*} \\
(0.95)\end{array}$ \\
\hline Share of Intangible & $\begin{array}{c}1.32 * * * \\
(0.18)\end{array}$ & $\begin{array}{c}1.32^{* * *} \\
(0.17)\end{array}$ & $\begin{array}{c}-0.11^{* * *} \\
(0.04)\end{array}$ & $\begin{array}{c}1.27^{* * *} \\
(0.20)\end{array}$ & $\begin{array}{c}-0.17^{* * * *} \\
(0.06)\end{array}$ & $\begin{array}{c}1.10 * * * \\
(0.26)\end{array}$ \\
\hline Labor Prod. & $\begin{array}{c}1.01^{* * *} \\
(0.03)\end{array}$ & $\begin{array}{c}0.68 * * * \\
(0.05)\end{array}$ & $\begin{array}{c}-0.12^{* * *} \\
(0.01)\end{array}$ & $\begin{array}{c}0.97^{* * *} \\
(0.06)\end{array}$ & $\begin{array}{c}-0.07 * * * \\
(0.01)\end{array}$ & $\begin{array}{c}0.61^{* * *} \\
(0.08)\end{array}$ \\
\hline Acquisition & $\begin{array}{c}1.15^{* * *} \\
(0.05)\end{array}$ & $\begin{array}{c}0.31^{* * *} \\
(0.03)\end{array}$ & $\begin{array}{l}-0.01 \\
(0.01)\end{array}$ & $\begin{array}{c}1.15^{* * *} \\
(0.05)\end{array}$ & $\begin{array}{c}-0.01 \\
(0.01)\end{array}$ & $\begin{array}{c}0.31^{* * *} \\
(0.04)\end{array}$ \\
\hline MNE Status & $\begin{array}{c}1.48 * * * \\
(0.05)\end{array}$ & & $\begin{array}{c}-0.11^{* * *} \\
(0.01)\end{array}$ & $\begin{array}{c}1.44^{* * *} \\
(0.06)\end{array}$ & & \\
\hline Audit Prob. (Adj.) & & & $\begin{array}{c}0.02 * * * \\
(0.00)\end{array}$ & & $\begin{array}{c}0.01^{* * * *} \\
(0.00)\end{array}$ & \\
\hline Sector $\times$ Period FE & Yes & Yes & Yes & Yes & Yes & Yes \\
\hline Firm FE & No & Yes & No & No & Yes & Yes \\
\hline Sample & & $\mathrm{Wi}$ & t Delaware & Is Incorpora & State & \\
\hline Obs. & 7,902 & 6,217 & 7,902 & 7,902 & 6,217 & 6,217 \\
\hline Number of Firms & 3607 & 1930 & 3607 & 3607 & 1930 & 1930 \\
\hline Adj. $\mathrm{R}^{2}$ & 0.585 & 0.926 & 0.247 & & 0.654 & \\
\hline KP F-stat. & & & & 107.1 & & 13.07 \\
\hline
\end{tabular}

The dependent variable is the firm's log sales at the end of the six-year window. OLS and 2LS estimates with robust standard errors in parentheses. First stage Kleibergen-Paap rk Wald $\mathrm{F}$ statistic reported. ***, ${ }^{* *}$, and ${ }^{*}$ significantly different from 0 at the $1 \%, 5 \%$, and $10 \%$ confidence levels, respectively. 